\title{
Racemic Phospholipids for Origin of Life Studies ${ }^{\dagger}$
}

\author{
Emiliano Altamura ${ }^{1, \mp(1)}$, Arnaud Comte ${ }^{2, \mp(}$, Alice $D^{\prime}$ Onofrio ${ }^{1,2, \S} \oplus$, Charlotte Roussillon ${ }^{2}$,

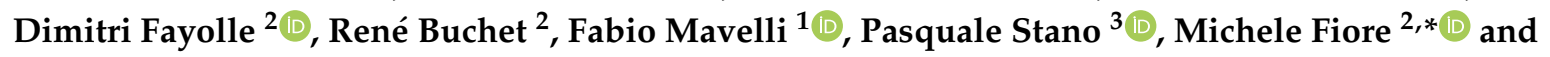 \\ Peter Strazewski ${ }^{2, *}$ \\ 1 Chemistry Department, Università degli studi di Bari “Aldo Moro", Via Orabona 4, 70125 Bari, Italy; \\ emiliano.altamura@uniba.it (E.A.); alicedonofrio@ctn.tecnico.ulisboa.pt (A.D.); fabio.mavelli@uniba.it (F.M.) \\ 2 Institut de Chimie et de Biochimie Moléculaires et Supramoléculaires (UMR 5246), Université Claude \\ Bernard Lyon 1, Université de Lyon, Bât. Edgar Lederer, 1 rue Victor Grignard, CEDEX, \\ F-69622 Villeurbanne, France; arnaud.comte@univ-lyon1.fr (A.C.); \\ charlotte.roussillon@etu.univ-lyon1.fr (C.R.); dimitri.fayolle@univ-lyon1.fr (D.F.); \\ rene.buchet@univ-lyon1.fr (R.B.) \\ 3 Department of Biological and Environmental Sciences and Technologies (DiSTeBA), University of Salento, \\ Strada Provinciale Lecce-Monteroni, Ecotekne, 73100 Lecce, Italy; pasquale.stano@unisalento.it \\ * Correspondence: michele.fiore@univ-lyon1.fr (M.F.); piotr.strazewski@univ-lyon1.fr (P.S.) \\ $\dagger \quad$ In memory of Océane. \\ $\ddagger$ Equal contribution. \\ $\S$ Current address C2TN-Centro de Ciências e Tecnologias Nucleares, Instituto Superior Técnico, \\ Universidade de Lisboa, 1649-004 Lisbon, Portugal.
}

Received: 27 May 2020; Accepted: 30 June 2020; Published: 3 July 2020

\begin{abstract}
Although prebiotic condensations of glycerol, phosphate and fatty acids produce phospholipid esters with a racemic backbone, most experimental studies on vesicles intended as protocell models have been carried out by employing commercial enantiopure phospholipids. Current experimental research on realistic protocell models urgently requires racemic phospholipids and efficient synthetic routes for their production. Here we propose three synthetic pathways starting from glycerol or from racemic solketal ( $\alpha, \beta$-isopropylidene-DL-glycerol) for the gram-scale production (up to $4 \mathrm{~g}$ ) of racemic phospholipid ester precursors. We describe and compare these synthetic pathways with literature data. Racemic phosphatidylcholines and phosphatidylethanolamines were obtained in good yields and high purity from 1,2-diacylglycerols. Racemic POPC (rac-POPC, $(R, S)-1$-palmitoyl-2-oleoyl-3-phosphocholine), was used as a model compound for the preparation of giant vesicles (GVs). Confocal laser scanning fluorescence microscopy was used to compare GVs prepared from enantiopure ( $R$ )-POPC), racemic POPC (rac-POPC) and a scalemic mixture (scal-POPC) of $(R)$-POPC enriched with rac-POPC. Vesicle morphology and size distribution were similar among the different (R)-POPC, rac-POPC and scal-POPC, while calcein entrapments in (R)-POPC and in scal-POPC were significantly distinct by about $10 \%$.
\end{abstract}

Keywords: organic synthesis; racemic phospholipid esters; stereochemistry; phosphadidylcholine; phosphatidylethanolamine; membranes; origin of life

\section{Introduction}

In a series of papers published in 1848, Louis Pasteur argued that the crystals of both (+)-tartaric and (-)-tartaric acids were composed of the same molecules, albeit bearing different symmetries. When combined in what is now called a racemic mixture, the different molecules cancelled each other's ability to rotate the direction of uniformly polarized light; he described these samples as "dissymmetric crystals facing one another in a mirror" [1]. At the time, Pasteur probably ignored the fact that he 
was giving birth to one of the major questions of natural sciences: given that racemic mixtures are produced in any achiral environment, and that both mirror-imaged molecular forms, now called enantiomers, have, to the limits of detection, exactly identical energies and reactivity, how did the biological homochiral world emerge from the primitive inanimate and achiral environment? In other words, the big question is not the appearance of chiral molecules, but how the population symmetry of dissymmetric objects was broken, that is, the fact that dissymmetric objects of the same potential energy became strongly unequally populated [2].

Indeed, a stochastic formation of dimers (or any n-mers), accompanied by a differential stability/activity of homochiral structures when compared to the heterochiral structures, can be included in the causes accounting for the evolution to our contemporary homochiral world [3]. Moreover, chemical reactions can amplify-by autocatalysis-an initially small enantiomeric imbalance; the Soai reaction is a most prominent example [4-6]. The experimental investigation on symmetry breaking and on the propagation of homochirality in primitive times has made progress over the years.

Phospholipids are clearly more complex than the simpler amphiphiles such as fatty acids [7], mono-alkyl phosphates [8-11], and isoprenoids [12], and most probably they participated in the formation of protocellular membranes together with several other components [13]. Phospholipids, in addition to their chemical diversity of headgroups and tails, are chiral molecules. Theory predicts and experimental evidence confirms that phospholipids form abiotically as racemic mixtures [14-19]. The starting materials (i.e., glycerol and fatty acids for the formation of diacylglycerols) are achiral and primordial non-enzymatic condensation reactions do not lead to any symmetry breaking. On the other hand, although it can be speculated that chiral phospholipids could arise in scalemic or enantiopure forms thanks to supposedly available chiral and markedly non-racemic catalysts such as peptides [20], RNA [21,22] or chiral crystals $[16,23,24]$, to date there are no experimental clues to support such a hypothesis. A few examples are represented by the chiral recognition of L-amino acids by liposomes prepared from $(S)$-phosphocholines [25] or enantioselective reactions carried out in liposomes driven by the presence of L-proline [26].

From the above-mentioned considerations, efficient synthetic routes to prepare racemic phospholipids are needed to extend studies of primitive membrane models. Racemic, scalemic (non-racemic not enantiopure either), and enantiopure phospholipid systems, alone or in a mixture with their precursors (such as fatty acids, mono- and diacylglycerols), must be investigated to address relevant questions of how primitive and most likely racemic phospholipids evolved toward enantiopure phospholipids (Figure 1). For example, do racemic, scalemic or enantiopure phospholipids self-assemble into membranes containing different properties with respect to membrane stability, encapsulation capacity and permeation of chiral molecules such as peptides, enzymes [27-30] or achiral molecules such as calcein [18,31]? Are they able to sustain dynamical processes such as shrinking, swelling, growth and division [32,33]? Are the processes occurring in their hydrophobic domain significantly affected by enantiomeric excesses [34]? Enantiomer-enriched (scalemic) membranes could affect the "symmetry breaking" of phospholipids themselves, as well as of other biomolecules, by providing a matrix for enantiomer selection at the supramolecular level. Such mechanisms would have been critical during early stages of protocell evolution and before the onset of homochirality as we know it today.

Although the preparation of enantiopure phospholipid esters has been extensively reviewed during the past forty years $[35,36]$, to the best of our knowledge, no large-scale synthesis of racemic phospholipids has ever been reported. The syntheses are usually reported at small scales, except for few chiral building blocks that are expensive or not easy to produce, such as (S)-2,3-O-isopropylideneglycerol ((S)-solketal) [37], (S)-glycidol [38], and L-glyceric acid [39]. D-Mannitol derivatives and D-or L-serine were also extensively used as chiral educts [36]. Thus, we prepared racemic phospholipids by optimizing the synthetic routes that were used for their enantiopure congeners. Four racemic phosphatidylcholines (1a-1d, Figure 1) and three racemic phosphatidylethanolamines (2a-2c, Figure 1) were synthetized from four different key racemic 1,2-diacylglycerols using different chemical pathways (Scheme 1). 
Commercially available achiral or racemic building blocks were used for the large-scale synthesis. In addition, POPC was selected as a model molecule to compare three distinct chemical synthetic pathways named A, B and C for its large-scale preparation (Scheme 1). The enantiopure precursor of (R)-POPC, 1-palmitoyl-2-oleoyl-sn-3-glycerol, was also synthesized in large scale from commercially available (S)-solketal, (S)-3b [37]. The characterizations of all compounds were performed via 1D and $2 \mathrm{D}{ }^{1} \mathrm{H}$ and ${ }^{13} \mathrm{C}$ NMR spectroscopy and mass spectrometry (cf. Materials and Methods, Appendix A). Comparisons of giant vesicles (GVs) made from commercial enantiopure $(R)$-POPC with those made from rac-POPC and scalemic mixtures, i.e., rac-POPC enriched with $(R)$-POPC in a 1:1 molar ratio (scal-POPC, R:S = 2:1), deriving from our synthetic pathways, were performed using confocal laser scanning microscopy analysis.

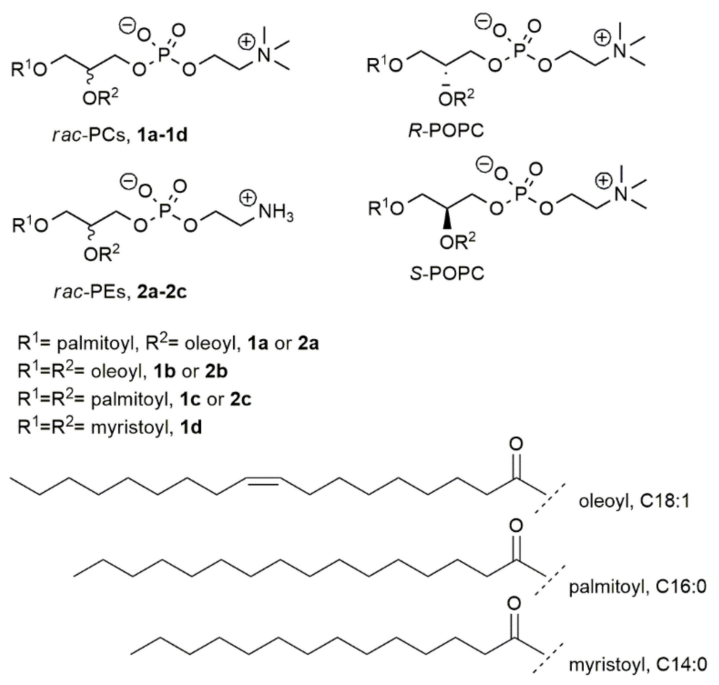

Figure 1. Chemical structures of the racemic phosphatidylcholines (1a-1d) and phosphatidyl ethanolamines (2a-2c); Rac-POPC (1a) was used as a model molecule for the study of large-scale synthesis. A racemic mixture of POPC is made of 50\% (R)-POPC and 50\% (S)-POPC; a mixture is termed scalemic when the ratio of enantiomers is different from 1:1 or 1:0 (0:1).

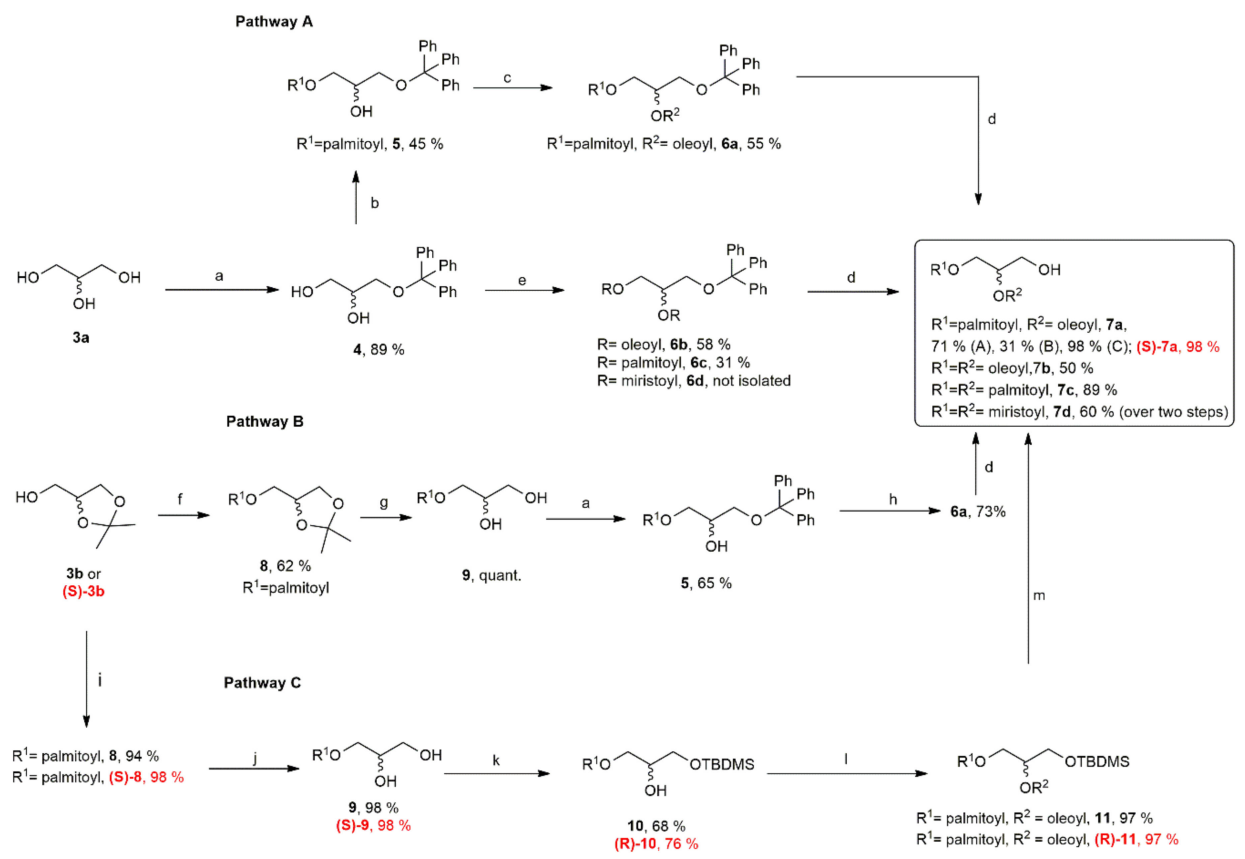

Scheme 1. Pathways A-C used for the synthesis of key compound 7a and schematic preparation of 
rac-DAG 7b-7d. (a) 3a, TrtCl (0.25 equiv.), DMAP (0.005 equiv.), $\mathrm{Et}_{3} \mathrm{~N}$ (0.03 equiv.) dry THF, 16 h, r.t.; (b) 4, Palmitic anhydride (1.1 equiv.), DMAP (1.1 equiv.), $\mathrm{CHCl}_{3}, 48 \mathrm{~h}, 0{ }^{\circ} \mathrm{C}$ to r.t.; (c) 5, oleic acid (1.3 equiv.), DMAP (1.3 equiv.), $\mathrm{EDC} \cdot \mathrm{HCl}$ (2.6 equiv.), pyridine (2.6 equiv.), dry $\mathrm{CH}_{2} \mathrm{Cl}_{2}, 16$ h, r.t.;

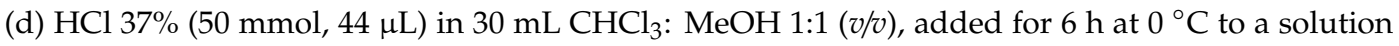
8a-8d dissolved in $30 \mathrm{~mL} \mathrm{CHCl}{ }_{3}: \mathrm{MeOH} \mathrm{1:1} \mathrm{(v/v),} \mathrm{then} 16 \mathrm{~h}$ at $0{ }^{\circ} \mathrm{C}$; (e) 4, acyl chlorides (1.3 equiv), DMAP (1.3 equiv), 16 h, r.t; (f) 3b, Palmitoyl chloride (1.25 equiv.), DMAP (1.25 equiv, dry $\mathrm{CH}_{2} \mathrm{Cl}_{2}$, 16 h, r.t.; (g) 9, Amberlyst-15, (1:10 w/w), dry $\mathrm{CH}_{2} \mathrm{Cl}_{2}, 4$ h, r.t.; (h) 5, oleoyl chloride (1.25 equiv.), DMAP (1.25 equiv.), dry $\mathrm{CHCl}_{3}, 16 \mathrm{~h}$ r.t.; (i) $3 \mathbf{b}$, Palmitic acid (1.1 equiv.), EDC. $\mathrm{HCl}$ (1.3 equiv.), DMAP (0.3 equiv.), dry $\mathrm{CH}_{2} \mathrm{Cl}_{2}, 16$ h, r.t.; (j) 8, $\mathrm{AcOH}: \mathrm{H}_{2} \mathrm{O}(4: 1 \mathrm{v} / \mathrm{v}), 2 \mathrm{~h}, 55^{\circ} \mathrm{C}$; (k) 9, TBDMSCl (1.1 equiv.), imidazole (1.5 equiv.), dry $\mathrm{CH}_{2} \mathrm{Cl}_{2}, 16 \mathrm{~h}$, r.t.; (l) 10 or (R)-10, oleic acid (1.1 equiv.), $\mathrm{EDC} \cdot \mathrm{HCl}$ (1.3 equiv.), DMAP (0.3 equiv.), dry $\mathrm{CH}_{2} \mathrm{Cl}_{2}, 16 \mathrm{~h}$ r.t; (m) 11 or (R)-11, $\mathrm{Et}_{3} \mathrm{~N} \cdot 3 \mathrm{HF}$ (5 equiv.) in THF:MeCN (1:1 v/v), 7 h, r.t.

\section{Results}

Racemic phospholipids were produced by first acylating a suitably protected racemic glycerol, then phosphorylating it. This strategy resembles the expected prebiotic formation of phospholipids [18,40]. As a model molecule for our speculation, racemic 1,2-dioleoylglycerol was synthesized under conditions identical to those reported for the naturally occurring enantiopure diacylglycerols [39]. The molecule was prepared at a medium-scale and this was crucial for carrying out a study on the properties of the resulting vesicles with no parsimony of starting material [18]. The three different chemical pathways bear the advantage of using pro-chiral compounds such as glycerol (3a), or racemic mixtures of glycerol derivatives, such as $\alpha, \beta$-isopropylidene-DL-glycerol (3b, rac-solketal). Both molecules represent very good sources of starting material for the preparation of racemic phospholipid esters [41].

\subsection{Synthesis of Racemic Di-Acyl Glycerols $7 a-7 d$}

\subsubsection{Pathway A}

Glycerol (3a) served as a common pro-chiral building block for the synthesis of four different racemic diacyl glycerols ( $r a c-D A G, 7 a-7 d$, Scheme 1). The preparation of rac-DAGs bearing two different acyl chains (7a) required one or two additional steps compared with the synthesis of those bearing two identical acyl chains $(\mathbf{7 b}-\mathbf{7 d}$, Scheme 1$)$. The derivative $3 \mathbf{a}$ was protected on a 10 -gram scale with triphenylmethyl chloride ( $\mathrm{TrtCl})$, catalytic 4-dimethylaminopyridine (DMAP) and triethylamine $\left(\mathrm{Et}_{3} \mathrm{~N}\right)$ to afford the product 4 in very good yields (89\%) after precipitation from dichloromethane/pentane (1:10, $v / v$ ) [39]. 1-Palmitoyl-3-trityl-glycerol (5) was obtained upon the reaction of 4 with palmitic anhydride in the presence of DMAP. After $48 \mathrm{~h}$, the product was obtained in a modest $45 \%$ yield due notably to the difficult removal of residual palmitic acid in the crude mixtures. The insertion of the oleoyl chain was performed by reacting 5 with oleic acid, DMAP and $N$-(3-dimethylaminopropyl)- $N^{\prime}$-ethylcarbodiimide hydrochloride $(\mathrm{EDC} \cdot \mathrm{HCl})$ in dry $\mathrm{CH}_{2} \mathrm{Cl}_{2}$. The overnight reaction, followed by purification over a silica gel column, yielded $\mathbf{6 a}$ in a decent yield (55\%). The key compound 7a was obtained from $6 \mathbf{6}$ by slight modifications of previously reported conditions [39] and with an improved yield (71\%). Dilute $\mathrm{HCl}$ was added dropwise over $6 \mathrm{~h}$ to a diluted solution of $6 \mathrm{a}$ kept at $0{ }^{\circ} \mathrm{C}$ (Scheme 1 , step d). The reaction was left stirring overnight and allowed the complete deprotection of the trityl group avoiding the acyl migration inconvenience previously observed [18]. The overall yield of 7a using pathway A was 16\% as reported in Table 1, entry 1 . Racemic $\mathbf{7 b}-\mathbf{7 d}$ bearing, respectively, two oleoyl, two palmitoyl or two myristoyl chains, were obtained by reacting the product 4 with the corresponding acyl chlorides in the presence of DMAP. These reactions were also performed on a gram-scale and the products were obtained with yields ranging from 31 to $58 \%$. The product $6 \mathrm{~b}$ and $6 \mathrm{c}$ were purified, while $6 \mathrm{~d}$ was recovered in a form sufficiently pure to omit further purification, allowing the overall yield of $7 \mathbf{d}$ to be drastically increased, as reported in Table A1 in Appendix A. 
Table 1. Synthesis of the key compounds $\mathbf{5 a}$ for the preparation of racemic compounds $\mathbf{1 a}-\mathbf{2 c}$.

\begin{tabular}{cccccc}
\hline Entry & Starting Material & Scale $^{\mathbf{1}}$ & Pathway & Compound & Overall Yield \\
\hline 1 & $3 \mathbf{a}$ & $4 \mathrm{~g}$ & $\mathrm{~A}$ & $7 \mathbf{a}$ & $16 \%$ \\
2 & $3 \mathbf{b}$ & $2 \mathrm{~g}$ & $\mathrm{~B}$ & $7 \mathbf{a}$ & $21 \%$ \\
3 & $3 \mathbf{b}$ & $3.7 \mathrm{~g}$ & $\mathrm{C}$ & $7 \mathrm{a}$ & $60 \%$ \\
4 & $(S)-3 \mathbf{b}$ & $3.7 \mathrm{~g}$ & $\mathrm{C}$ & $(S)-7 \mathrm{a}$ & $66 \%{ }^{2}$ \\
5 & 4 & $2.2 \mathrm{~g}$ & & $7 \mathbf{b}$ & $29 \%^{3}$ \\
6 & 4 & $1.0 \mathrm{~g}$ & & $7 \mathrm{c}$ & $28 \%^{3}$ \\
7 & 4 & $1.0 \mathrm{~g}$ & & $7 \mathrm{~d}$ & $60 \%{ }^{3,4}$ \\
\hline
\end{tabular}

${ }^{1}$ with respect to the starting material used; ${ }^{2}$ slightly increased yield is due to the higher chemical purity of the starting material used in step $\mathrm{m}$ in Scheme $1 ;{ }^{3}$ yield calculated over the steps e-d, Scheme $1 ;{ }^{4}$ non purified mixtures of $6 \mathbf{d}$ were directly used.

\subsubsection{Pathway B}

The key compound 7a was prepared alternatively starting from $\alpha, \beta$-isopropylidene-DL-glycerol (3b, Scheme 1, pathway B). The main difference with respect to pathway A was the introduction of the palmitoyl residue on the protected glycerol $\mathbf{3 b}$. The reaction was performed using palmitoyl chloride, instead of palmitic anhydride, in the presence of DMAP and in a slight excess with respect to $\mathbf{3 b}$ (1.25 eq.). The reaction was left stirring overnight and the desired product $\mathbf{8}$ was isolated in a good yield (62\%) and high purity. Compound 8 [42] was quantitatively deprotected using acidic Amberlyst ${ }^{\circledR} \mathrm{H}^{+}$resin and the primary alcohol of the resulting compound 9 was tritylated in conditions previously described [43]. The resulting compound 5, obtained with the same chemical purity as that obtained via pathway A, was then treated with oleoyl chloride and DMAP to obtain the product 6 a. The deprotection of the trityl group was performed as previously described affording the product $7 \mathbf{a}$ in $71 \%$ yield and good purity. The overall yield obtained using Pathway B was $21 \%$ as reported in Table 1 , entry 2 .

\subsubsection{Pathway C}

A third route for obtaining the compound 7a was also optimized. This pathway employed a different protecting group, a tert-butyl-dimethylsilyl ether (TBDMS) to protect the terminal alcohol of the monoacyl glycerol 9 [42]. The first reaction was the Steglich esterification [44] of $\alpha, \beta$-isopropylidene-DL-glycerol ( $3 \mathbf{b}$ or commercially enantiopure solketal,(S)-3b) [37], using palmitic acid, EDC as the coupling agent and DMAP, to obtain the desired compound 8 in quantitative yield. The isopropylidene moiety was then removed by treatment of 8 with aqueous acetic acid at $55^{\circ} \mathrm{C}$ (Scheme 1, step j). The primary alcohol of resulting product 9 [43] was selectively protected as silyl derivative 10 [45] using tert-butyl-dimethylsilyl chloride and imidazole as a catalyst. The same esterification conditions applied for the synthesis of $\mathbf{8}$ were applied to obtain compound $\mathbf{1 0}$ and $11[39,46,47]$ that were isolated almost quantitatively. The deprotection of the silyl group was achieved using a five-fold molar excess of triethylamine tris(hydrofluoride) in a 1:1 mixture of MeCN and THF [48] to yield the final compound rac-POG 7a. As described in the literature [49], this sequence using a silyl protecting group is often more efficient, especially during the deprotection step, than the more common trityl-based strategies (pathway A or B). In fact, the deprotection of the trityl group often leads to undesired products due to the acyl chain migration in acidic medium and suffers from a slow rate of deprotection. In contrast, the hindered chlorosilane reagents enable the protection of primary alcohols with yields varying from 60 to $90 \%$ and a clean removal using a source of fluoride $\left(\mathrm{Et}_{3} \mathrm{~N}\right.$ or pyridine $\mathrm{HF}$ adducts, or TBAF) with near quantitative yields. Using pathway $\mathrm{C}$, the overall yield of $7 \mathbf{a}$ was $60 \%$ and the enantiopure (S)-7a following the same reaction pathway was synthesized with an overall yield of $66 \%$ (Table 1, entries 3 and 4 , respectively). 


\subsection{The Next-To-Last Step: the Introduction of the Phospholipid Headgroup}

Compounds $\mathbf{7 a}-\mathbf{7} \mathbf{d}$ were used to prepare the corresponding PCs $(\mathbf{1 a}-\mathbf{1 d})$ and PEs $(\mathbf{2 a}-\mathbf{2 c})$ via cyclic phosphotriester intermediates 13a-13d by nucleophilic addition of dry trimethylamine or ammonia (Scheme 2). The synthetic procedures are well known [9] and the racemic diacyl glycerols 7a-7d obtained following pathways A-C were used. Purifications of the crude materials were carried out using flash chromatography as reported in Appendix A.

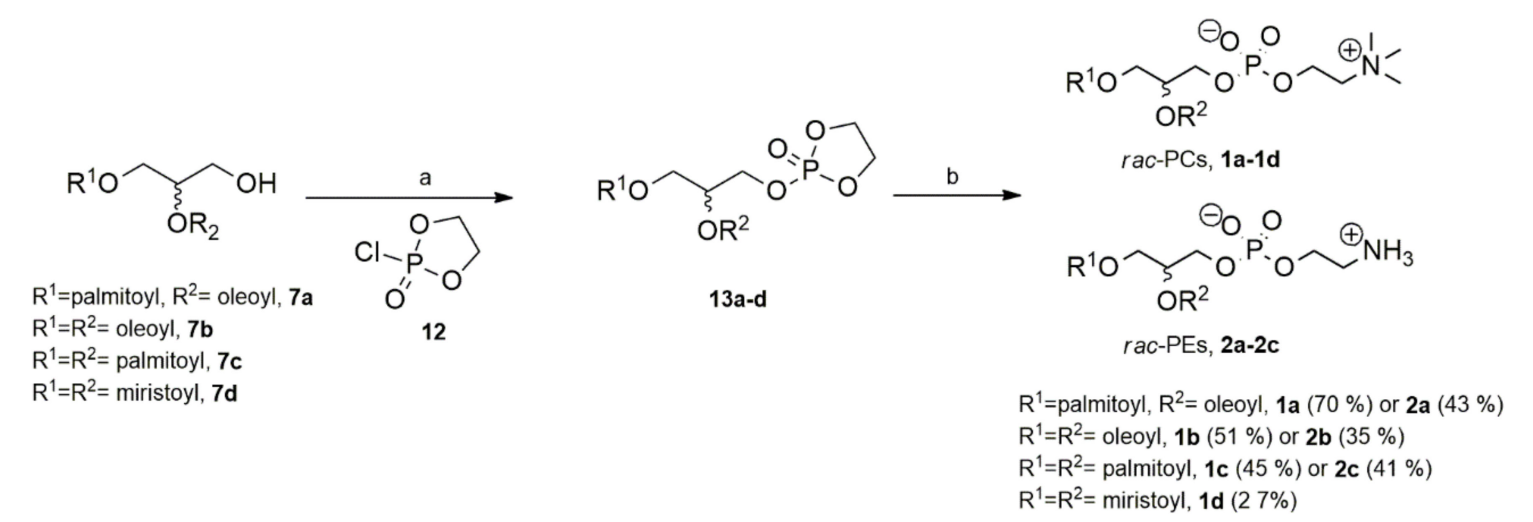

Scheme 2. Synthesis of racemic $1 \mathbf{1 a}-\mathbf{1 d}$ and 2a-2c. (a) $\mathbf{7 a - d}, \mathbf{1 2}$ (1.0 equiv.), $\mathrm{Et}_{3} \mathrm{~N}$ (1.1 equiv.), dry $\mathrm{CH}_{3} \mathrm{CN}$, $0{ }^{\circ} \mathrm{C}$ to r.t. $1 \mathrm{~h}$; (b) 13a-d, $\mathrm{NMe}_{3}$ (3.5 equiv.), dry $\mathrm{CH}_{3} \mathrm{CN}, 16 \mathrm{~h}, 65^{\circ} \mathrm{C}$; or $\mathbf{1 3 a}-\mathbf{c}, \mathrm{NH}_{3}$ (3.5 equiv.), dry $\mathrm{CH}_{3} \mathrm{CN}, 16 \mathrm{~h}, 65^{\circ} \mathrm{C}$.

\section{Comparison of Giant Vesicles Made from (R)-POPC with Those Made from Racemic and Scalemic Mixtures of Rac-POPC and Scal-POPC}

POPC served as a model compound for the preparation of GVs. In particular, we compared enantiopure membranes made of (R)-POPC with racemic membranes made of the synthesized rac-POPC, and with membranes made of a scalemic mixture $(R / S$ molar ratio $=2: 1)$. Typical giant vesicles produced in this work are shown in Figure 2. The scalemic mixture was prepared by adding to rac-POPC the naturally occurring commercially available (R)-POPC, thus, avoiding the eight-step synthesis from (S)-glycidol of non-natural and non-commercial (S)-POPC [50].

GVs are very large vesicles, the diameters of which lie in the micrometer range $(1-100 \mu \mathrm{m})$. For this reason, they can be directly observed by optical microscopy rather than using indirect methods [51]. In this study we have used the so-called "droplet transfer" method, originally devised by Weitz and collaborators $[52,53]$ and widely used in the community of protocell researchers for constructing solute-filled GVs for the purpose of studying protocell models [34].

The key mechanism of the droplet transfer method is the formation of vesicular bilayer membranes while lipid-stabilized water-in-oil droplets cross a flat interface where other lipid molecules are aligned in a monolayer [52]. In this step, the lipids coating a droplet and the lipids aligned at the flat interface come into close tail-to-tail contact and form the hydrophobic core of the membrane, while the polar headgroups of all lipids are facing the aqueous phases. In other words, the membrane assembly takes into account both lipid/water and lipid/lipid interactions. The droplet transfer is facilitated by centrifugation [30]. The method is sensitive to the type of lipids employed for the aforementioned reasons, i.e., different molecular structures generate different intermolecular interactions, thus affecting the overall droplet transfer efficiency [29,30,52].

The visual inspection of microscopy images (Figure 2) revealed no major morphological differences between the three samples suggesting that under the experimental conditions tested (low ionic strength, high sugar concentration, $25^{\circ} \mathrm{C}$ ) the POPC chirality was not critical to the primary goal of forming GVs. Moreover, the green fluorescence detected inside GVs confirmed that in all cases the entrapment 
of solutes was clearly achievable. These two essential conclusions are key pre-requisites for the future employment of racemic GVs in this field.
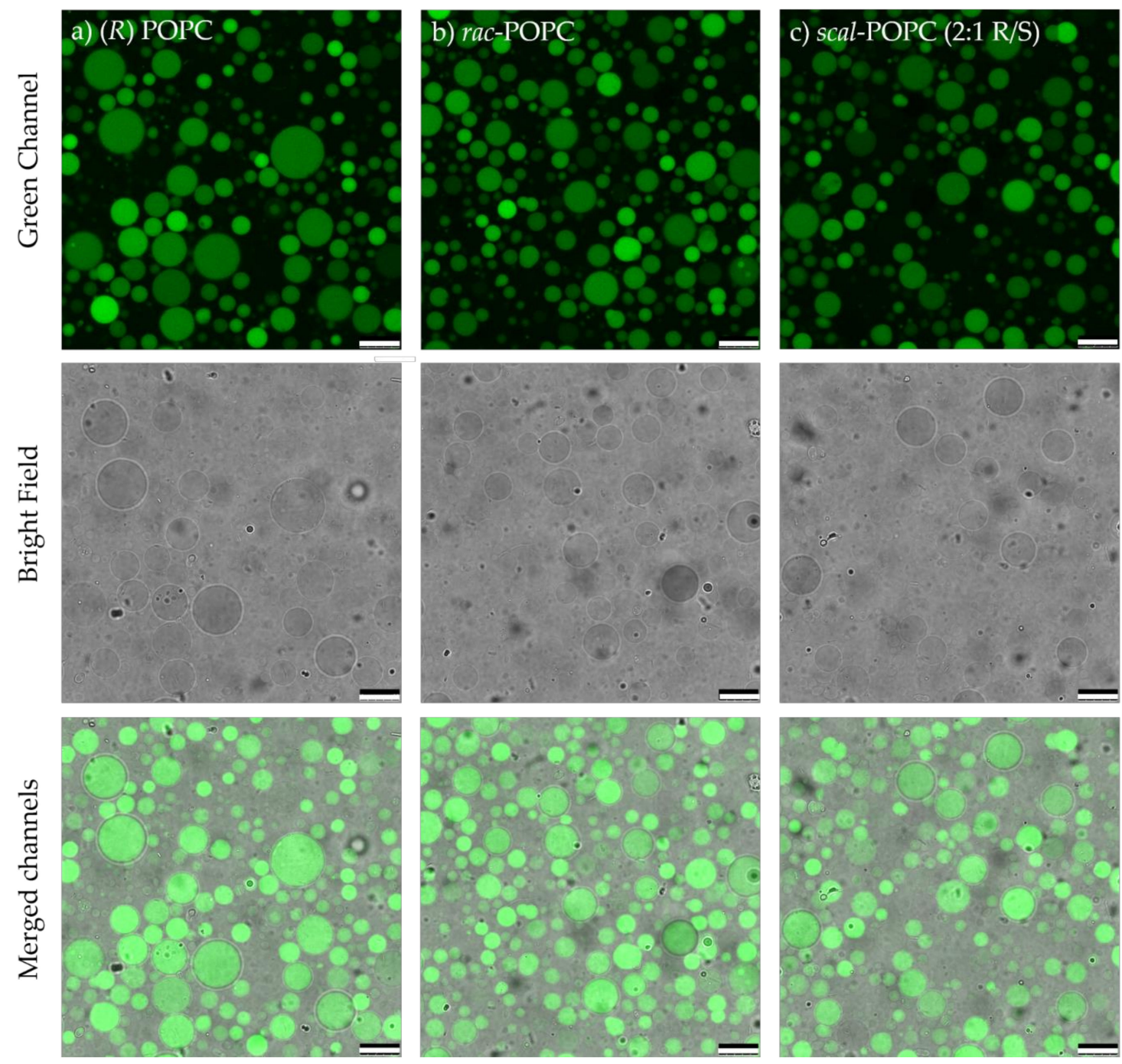

Figure 2. Confocal micrographs of the vesicles obtained from enantiopure (column a), racemic (column b) and scalemic (R:S, 2:1 column c) POPC GVs were imaged with a SP8 X laser scanning confocal microscope (Leica Microsystems, Wetzlar, Germany). Calcein $(20 \mu \mathrm{M})$ was included in the inner aqueous buffer to mark the vesicle lumen and largely washed out from the outside by replacing with calcein-free outside buffer. Calcein fluorescence is evident in the green channel row, while the vesicle contours are shown in the bright field image row. The green fluorescence confinement is clearly shown in the merged channels row. Scale bar is $30 \mu \mathrm{m}$ for all the micrographs.

To further evaluate the possible differences among GVs made of homochiral, racemic and scalemic POPC mixtures, quantitative analyses are needed. For example, comparing the size distribution, the concentration of entrapped solutes, and especially the biophysical properties of the membrane will shed light on how phospholipid chirality affects self-assembly, dynamics, and their interactions at the supramolecular level of a bilayer membrane. While detailed investigations on these aspects are postponed to future studies, a preliminary account of vesicle size and content is given in Figure 3 (see legend for the numerical values). 

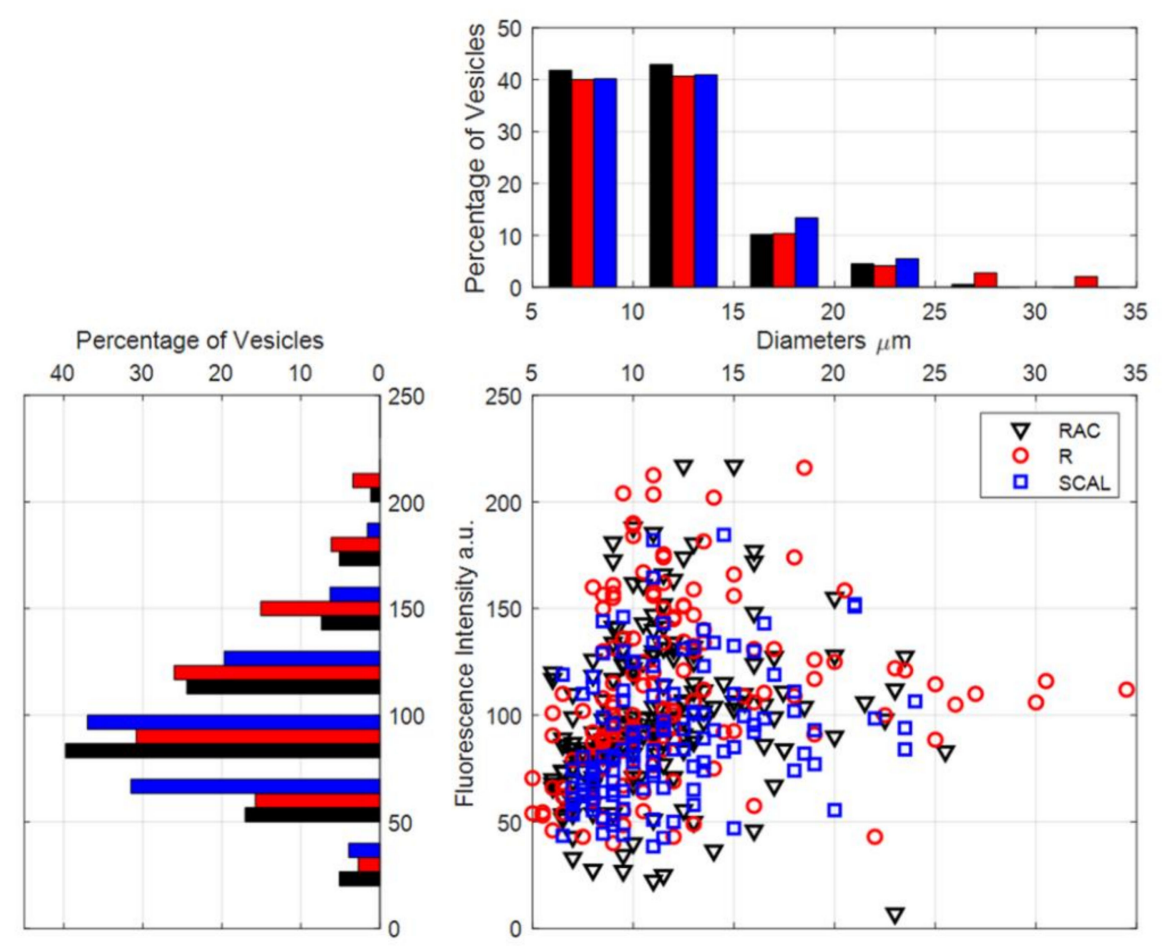

Figure 3. Quantitative image analysis of GVs made of rac-POPC (black), (R)-POPC (red), scal-POPC (blue). The dot plot shows the values of diameters ( $\mu \mathrm{m}$, on the $\mathrm{x}$-axis) and internal fluorescence (a.u., on the y-axis) for each individual GV (i.e., each point represents one GV). The two histograms on the top and on the left of the dot plot show, respectively, the size distribution and the fluorescence distribution of the three populations. Means and standard deviations of the GV populations: rac-POPC $(n=177)$, diameter $11.1 \pm 3.8 \mu \mathrm{m}$, fluorescence $100 \pm 37$ a.u.; $(R)$-POPC $(n=146)$, diameter $11.9 \pm 5.3 \mu \mathrm{m}$, fluorescence $110 \pm 40$ a.u.; scal-POPC $(n=127)$, diameter $11.6 \pm 3.9 \mu \mathrm{m}$, fluorescence $90 \pm 30$ a.u.

The diameter $(\mu \mathrm{m})$ and the internal fluorescence (a.u.) of each GV in three samples (rac-POPC, $(R)-P O P C$, scal-POPC) were measured by quantitative image analysis and reported as dot plots in Figure 3. The three different populations largely clustered in the same region of the diameterfluorescence dot-plot, qualitatively showing their similar structure and size-content relationship. A quantitative Kolmogorov-Smirnov analysis of the size distributions (Figure 3, top histogram) and fluorescence distributions (Figure 3, left histogram) revealed that the size distributions of the three samples were not statistically different at the $95 \%$ confidence level. The only statistically significant difference was detected between the calcein fluorescence distributions of $(R)$-POPC and scal-POPC GVs as indicated by Kruskal-Wallis ANOVA $(p<0.01)$ because their distributions were not normal.

Accordingly, $10 \%$ variation in the average fluorescence intensity was observed. Such a variation is consistent with the solute entrapment variability throughout the vesicle formation [54]. However, another intriguing explanation could refer to the mechanism of GV formation. Since a lipid monolayer should be transformed into a lipid bilayer (see original reports for details), supramolecular interactions can play a crucial role during the assembly. The excess of one enantiomer in the scal-POPC could be the origin of membrane defects, possibly located between lipid micro-domains, which would lead to a partial release of calcein. Such defects could play a role in dynamic behavior of the vesicle membrane and in the long-term release of the solutes affecting the permeability of the lipid bilayer.

\section{Discussion}

Our findings demonstrate that it is possible to prepare, from cheap and commercially available starting materials, racemic phospholipids in high chemical purity at a $\geq 1 \mathrm{~g}$ scale. 
In particular, we obtained four different PCs and three PEs. Since racemic diacyl glycerols are the essential compounds for the preparation of the desired racemic phospholipids, our interest was focused on the synthesis of these derivatives. The key compounds $7 \mathbf{a}-7 \mathbf{d}$ were prepared in moderate yields from commercially available glycerol (3a) using the described Pathway A. The same synthetic route served also to prepare the derivatives bearing two identical acyl chains, $7 \mathbf{b}-\mathbf{7 d}$, with high yields (50-89\%) as described in Table 1, entries 5-8. The synthesis of such compounds presented significant experimental advantages, as it involved a lower number of synthetic steps from the starting material 3a and, in addition, the presence of two identical esters, thus, escaping the problem of acyl migration encountered in the preparation of $7 \mathbf{a}$. Although the chemical purification of intermediate compounds $\mathbf{6 b}-\mathbf{6} \mathbf{d}$ was expected to be quite challenging, the purification proceeded smoothly and with a very low loss of material. The compound $7 \mathbf{a}$ was obtained in higher yields when using Pathway B, starting from $\alpha, \beta$-isopropylidene-DL-glycerol ( $3 \mathbf{b})$ protected with a triphenylmethyl group. However, the best results, with excellent overall yield, were obtained via Pathway $C$ that involved the use of a tert-butyl-dimethylsilyl ether in the key synthetic step. This protecting group allowed the overall yields to be increased from 16 to $60 \%$. The synthesis of the enantiopure (S)-7a, prepared from commercial (S)-solketal, further improved the overall yield to $66 \%$ as shown in Table 1.

In particular, using sterically hindered chlorosilane reagents allowed for the primary alcohol protection with yields varying from 60 to $90 \%$, as well as their clean removal with a source of fluoride $\left(\mathrm{Et}_{3} \mathrm{~N}\right.$ or pyridine HF adducts, or TBAF) in near quantitative yields. The last steps for the preparation of the target compounds 1a-2c were performed accordingly to the reported synthetic procedures. Yields and purity were higher with respect to any reported data (Appendix A) [39,42,43,45,50,55]. We also produced GVs made of (R)-POPC, rac-POPC and a scalemic mixture (scal-POPC) made of $(R: S=2: 1)$ POPC enantiomers (Figures 2 and 3 ). The feasibility of building GVs either with enantiomeric (R)-POPC, rac-POPC or scal-POPC made of $R: S$ in 2:1 molar ratio was evident. Their respective morphologies were similar based on observations through confocal laser scanning microscopy. Statistical analyses revealed that the size distribution was not affected by the POPC chirality, whereas a low but statistically significant difference was detected between the calcein entrapment inside $(R)$-POPC (higher content) and scal-POPC (lower content). Although a possible cause for this difference might lie in the mechanisms of bilayer assembly in the very moment of droplet transfer and GV formation, available data did not allow further discussion. Additional physico-chemical characterizations are needed to ascertain their eventual distinct properties. In this respect, a meaningful example refers to racemic sphingomyelins, which significantly differ in their biophysical properties from the physiologically relevant D-erythro sphingomyelins [56].

\section{Future Research}

To address several unanswered questions on lipid synthesis in ancient times, two future research directions are proposed.

First, to further delineate the properties of chiral and racemic phospholipids, a more stringent physico-chemical analysis of vesicles (enantiopure, racemic, scalemic) will be performed: (a) Turbidity variation induced by shrinking and swelling vesicles as measured by UV spectrometry [57]. (b) Dynamic light scattering and/or spectrophotometry, to monitor morphologies as a function of temperature and the addition of cryoprotectants such as trehalose or other chiral mono/disaccharides. Racemic/enantiopure fatty acid vesicles made of chiral $\alpha$-methyl fatty acids behave differently under temperature stress, the homochiral ones being more stable [58]. (c) Effects of detergents such as $\beta$-D-octylglucopyranoside or sodium cholate (both chiral) affecting the membrane permeability to peptides. (d) Vesicles doped with small amounts of anionic surfactants and subjected to the presence of cationic proteins to determine recognition property of vesicles. (e) Osmotic stress, under the above mentioned conditions. For example, the interaction between anionic vesicles and lysozyme revealed specific properties of vesicles [59-61]. Likewise, the opposite can be done, i.e., membranes doped with cationic lipids and interactions with polyanions (poly (Glu), nucleic acids, etc.). 
Second, to evaluate dynamical properties, such as the growth-division mechanism [32], GVs made of racemic or scalemic mixtures will be treated with enantiopure compounds such as chiral fatty acids [58] acting like detergents. The fatty acid uptake by GVs may destabilize the growth and division of GVs, a process that mimics the growth and division of cells. Parallel experiments can be run together with membranes stressed as described above. Such a combinatorial approach may reveal the stereochemical diversity and selection of modern membranes. In this context, racemic and scalemic mixtures of conveniently temperature-sensitive phospholipids can be used, e.g., 1,2-dipalmitoyl-sn-glycero-3-phosphocholine, DPPC (1c), showing $T_{\mathrm{m}}$ values above room temperature.

\section{Conclusions}

A series of racemic phosphatidylcholines and racemic phosphatidylethanolamines was synthetized from four different key racemic 1,2-diacylglycerols using different chemical pathways. The use of a silyl ether protecting group drastically increased the overall yields from 16 to $60 \%$ for a convenient gram scale scale-up synthesis of POPC. The synthesized racemic POPC was used for the construction of racemic membranes approaching primitive membranes before the onset of the homochiral bio-world that characterizes life as we know it (see next article in this issue). Generally speaking, here we have concluded that racemic and scalemic lipids, in particular POPC, form stable membranes essentially, as well as homochiral lipids. Such a decisive observation will pave the way to deeper investigations on the subject of homo/hetero-chiral primitive membranes. This work represents the first step for a systematic study of phospholipid chirality and its effect on many possible vesicle properties.

Author Contributions: Conceptualization: M.F.; methodology: M.F., E.A. and A.C.; investigation: equal contribution for all authors; resources, M.F. and P.S. (Peter Strazewski); data curation, equal contribution for all authors; writing-original draft preparation, M.F.; first review: M.F., P.S.(Pasquale Stano), R.B. and P.S. (Peter Strazewski); Electronic Supporting Information part, M.F. visualization, M.F.; supervision, M.F. and P.S. (Peter Strazewski); project administration, M.F. and P.S. (Peter Strazewski); funding acquisition, P.S. (Peter Strazewski); All authors have read and agreed to the published version of the manuscript.

Funding: This research was funded by Volkswagen Stiftung (Molecular Life, Az. 92 850)”. Collaboration between authors has been fostered by the European COST Action CM1304 on "Emergence and Evolution of Complex Chemical Systems.

Acknowledgments: MF dedicates this work to the memory of his daughter Océane (2015-2017). The European COST Action CM1304 on "Emergence and Evolution of Complex Chemical Systems" is gratefully acknowledged. The people at the Centre Commun de Spectrométrie de Masse (CCSM) and at the Centre Commun de RMN at the Institut de Chimie et de Biochimie Moléculaires et Supramoléculaires (UMR 5246) are gratefully acknowledged for their irreplaceable work done for this research.

Conflicts of Interest: The authors declare no conflict of interest.

\section{Abbreviations}

PE, petroleum ether; EtOAc, ethyl acetate; $\mathrm{AcOH}$, acetic acid; $\mathrm{MeCN}$, acetonitrile; THF, tetrahydrofurane; $\mathrm{Cy}$, cyclohexane; TRIS- $\mathrm{HCl}$, tris(hydroxymethyl)aminomethane hydrochloride; TBAF, tetramethylammonium fluoride.; TBDMSCl, tert-butyldimethylsilyl chloride; UV, ultra-violet.

\section{Appendix A. Materials and Methods, Preparation of Giant Vesicles and Chemical Characterization of Synthetic Compounds}

\section{Appendix A.1. Materials and Methods}

(R)-POPC was purchased from Avanti Polar Lipids, Alabaster AL (USA). All the other reagents, including calcein, glycerol, $(S)$-solketal, $\alpha, \beta$-isopropylidene-DL-glycerol, oleic acid and oleoyl chloride, palmitic acid, palmitic anhydride and palmitoyl chloride, myristoyl chloride, dimethylaminopyririne (DMAP) were purchased from Sigma-Aldrich (Paris, France), Thermo-Fisher Scientific (Dortmund, Germany) or TCI Europe (Paris Cedex 7, France) and were used without further purification. $\mathrm{NH}_{3}$ (N50) was purchased by Airliquide (75 Quai d'Orsay, 75321 Paris cedex 07, France). Solvents used for silica gel chromatography were purchased from Fisher Scientific (Hampton, New Hampshire, USA).

Silica was activated by heating at $200{ }^{\circ} \mathrm{C}$ overnight to avoid presence of humidity. 
Low temperature reactions were carried out using a Fryka KB06-40 (ProfiLab24 GmbH, Landsberger Str. 245, 12623 Berlin, Germany) or a Huber Minichiller 600 (Kältemaschinenbau AG, Werner-von-Siemens-Strasse 1, D-77656 Offenburg, Germany).

Thin-layer chromatography (TLC) was carried out on aluminum sheets coated with silica gel $60 \mathrm{~F}_{254}$ (Merck). TLC plates were inspected by UV light $(\lambda=254 \mathrm{~nm})$ and developed by treatment with a mixture of $10 \% \mathrm{H}_{2} \mathrm{SO}_{4}$ in $\mathrm{EtOH} / \mathrm{H}_{2} \mathrm{O}(1: 1 \mathrm{v} / \mathrm{v}), 10 \% \mathrm{KMnO}_{4}$ in $\mathrm{EtOH} / \mathrm{H}_{2} \mathrm{O}(1: 1 \mathrm{v} / \mathrm{v})$, or the Hanessian (Pancaldi) reagent $\left(\left(\mathrm{NH}_{4}\right)_{6} \mathrm{MoO}_{4}\right.$, $\left.\mathrm{Ce}\left(\mathrm{SO}_{4}\right)_{2}, \mathrm{H}_{2} \mathrm{SO}_{4}, \mathrm{H}_{2} \mathrm{O}\right)$ followed by heating.

Optical rotations were measured as $\mathrm{CHCl}_{3}$ solutions $(\mathrm{c}=0.01 \mathrm{~g} / \mathrm{L}$, unless specified otherwise) on a JASCO P-1010 digital polarimeter and converted to specific rotations $[\alpha]_{D}$.

HRMS analyses were performed on a Bruker Impact II quadrupole-time of flight mass spectrometer.

NMR spectra were recorded in $\mathrm{CDCl}_{3}$ on a Bruker Avance 300 spectrometer at $300 \mathrm{MHz}$ for ${ }^{1} \mathrm{H}, 75$ for ${ }^{13} \mathrm{C}$ and 121.5 for ${ }^{31} \mathrm{P}$ and on a Bruker Avance 400 spectrometer at $400 \mathrm{MHz}$ for ${ }^{1} \mathrm{H}$ and 100 for ${ }^{13} \mathrm{C}$. Chemical shifts of $\mathrm{CDCl}_{3}: \delta_{\mathrm{H}}=7.26$ and $\delta_{\mathrm{C}}=77.23$ served as internal references. Signal shapes and multiplicities are abbreviated as br (broad), s (singlet), d (doublet), t (triplet), q (quartet), quint (quintet) and m (multiplet). Where possible, a scalar coupling constant $J$ is given in Hertz $(\mathrm{Hz})$.

Microscopic images were recorded with a confocal laser scanning microscope Leica SP8 X. Samples $(5 \mu \mathrm{L})$ were placed in micro-welled plastic slides (ibidi $\mathrm{GmbH}$, Gräfelfing-Münich, Germany, \#81821). Images were recorded with a HCX PL APO lambda blue 40.0 N.A. 1.25 oil immersion objective: calcein fluorescence was acquired with excitation source at $488 \mathrm{~nm}$ selected wavelength of an argon laser and the emission recorded in the 500-600 nm range.

\section{Appendix A.2. Preparation of Giant Vesicles}

Giant vesicles (GVs) were obtained via the droplet transfer method [52], following an optimized procedure [30]. In a $1.5 \mathrm{~mL}$ Eppendorf tube (tube A) $300 \mu \mathrm{L}$ of organic phase consisting of $0.5 \mathrm{mM}$ phospholipids, (R)-POPC for enantiopure sample; rac-POPC for the racemic one; $2: 1$ ratio of $R$-POPC and rac-POPC for a scalemic mixture, dispersion in mineral oil (Sigma-Aldrich, \#M5904), were gently laid over $500 \mu \mathrm{L}$ of aqueous O-solution (outer solution, $200 \mathrm{mM}$ glucose, Tris- $\mathrm{HCl} 20 \mathrm{mM}$, $\mathrm{pH}$ 7.8)

In another $1.5 \mathrm{~mL}$ Eppendorf tube (tube B), $20 \mu \mathrm{L}$ of I-solution (inner solution: Tris- $\mathrm{HCl} 20 \mathrm{mM} \mathrm{pH} \mathrm{7.8,}$ $200 \mathrm{mM}$ sucrose, calcein $2 \mu \mathrm{M}$ ) were added to $600 \mu \mathrm{L}$ of $0.5 \mathrm{mM}$ phospholipids in mineral oil. A water-in-oil (w/o) emulsion was obtained by pipetting repeatedly up and down the mixture for $30 \mathrm{~s}$. Next, the w/o emulsion (tube B) was gently poured on top of the organic phase in tube A. Tube A was centrifuged at $2500 \mathrm{rpm}$ for $10 \mathrm{~min}$ at room temperature. After the centrifugation, the mineral oil appeared clear and was removed. The resulting GV pellets were collected from the bottom of the tube by direct aspiration with a polypropylene micropipette tip $(50 \mu \mathrm{L})$. The vesicles were washed twice by centrifugation, supernatant removal, and re-suspension in fresh O-solution to remove most of the non-entrapped substances.

\section{Appendix A.3. Chemical Synthesis}

3-O-Triphenylmethyl-DL-glycerol (4). To a stirred solution of glycerol (3a, $10.0 \mathrm{~g}, 109.6 \mathrm{mmol})$, DMAP $(0.075 \mathrm{~g}, 0.6 \mathrm{mmol})$ and trityl chloride $(7.5 \mathrm{~g}, 26.9 \mathrm{mmol})$ in $20 \mathrm{~mL}$ of anhydrous THF at $0{ }^{\circ} \mathrm{C}$ were added $4.5 \mathrm{~mL}$ of anhydrous triethylamine. The reaction mixture was stirred at r.t. overnight. A solution of $\mathrm{NaHCO}_{3}(2.0 \mathrm{~g}$ in $50 \mathrm{~mL}$ of $\left.\mathrm{H}_{2} \mathrm{O}\right)$ was added followed by stirring for $15 \mathrm{~min}$. The product was then extracted with EtOAc $(2 \times 35 \mathrm{~mL})$. The combined organic phases were washed with brine $(2 \times 50 \mathrm{~mL})$ and dried over anhydrous $\mathrm{Na}_{2} \mathrm{SO}_{4}$. The crude material obtained after evaporation of the solvent was crystallized from dichloromethane upon addition of pentane $(1: 10 \mathrm{v} / \mathrm{v})$ to give $32.57 \mathrm{~g}(89.7 \%)$ of a white powder containing $4 . \mathrm{R}_{\mathrm{f}}$ (hexane/EtOAc $\left.1: 1 \mathrm{v} / \mathrm{v}\right) 0.42 ;{ }^{1} \mathrm{H}$ NMR $\left(400 \mathrm{MHz}, \mathrm{CDCl}_{3}\right): \delta_{\mathrm{H}}=7.49-7.12(\mathrm{~m}, 15 \mathrm{H}, 3 \times \mathrm{Ph}), 3.85-3.79(\mathrm{~m}, 1 \mathrm{H}, \mathrm{C}(2) \mathrm{H}), 3.63(\mathrm{dd}, J=11.4,3.8 \mathrm{~Hz}$, $1 \mathrm{H}, \mathrm{C}(3) \mathrm{Ha}), 3.55(\mathrm{dd}, J=11.4,5.7 \mathrm{~Hz}, 1 \mathrm{H}, \mathrm{C}(3) \mathrm{Hb}), 3.26-3.16\left(\mathrm{~m}, 2 \mathrm{H}, \mathrm{C}(3) \mathrm{H}_{2}\right) ; 4 \mathrm{c}:{ }^{1} \mathrm{H} \mathrm{NMR}\left(400 \mathrm{MHz}, \mathrm{CDCl}_{3}\right)$ : $\delta \mathrm{H}=7.49-7.12(\mathrm{~m}, 15 \mathrm{H}, 3 \times \mathrm{Ph}), 3.97-3.89(\mathrm{~m}, 1 \mathrm{H}, \mathrm{C}(2) \mathrm{H}), 3.32-3.26\left(\mathrm{~m}, 4 \mathrm{H}, \mathrm{C}(1) \mathrm{H}_{2}\right.$ and $\left.\mathrm{C}(3) \mathrm{H}_{2}\right) ;{ }^{13} \mathrm{C} \mathrm{NMR}$ $\left(100 \mathrm{MHz}, \mathrm{CDCl}_{3}\right.$, selected signals): $\delta_{\mathrm{C}}=64.1$ (C1, HSQC), 64.8 (C3, HSQC), 70.6 (C2, HSQC), 71.1 (C2, HSQC), $86.8(\mathrm{CqAr}), 127.2-129.9$ (series of $\mathrm{CHAr}), 144.0\left(\mathrm{OC}(\mathrm{Ph})_{3}\right), 147.1\left(\mathrm{OC}(\mathrm{Ph})_{3}\right) ;[\alpha]_{\mathrm{D}}^{25}=0.00\left(\mathrm{c} 0.1, \mathrm{CHCl}_{3}\right) ; \mathrm{HRMS}^{25}$ $m / z:[\mathrm{M}]^{+}$calcd. for $\mathrm{C}_{22} \mathrm{H}_{22} \mathrm{NaO}_{3}: 357.1466$, found $\mathrm{C}_{22} \mathrm{H}_{22} \mathrm{NaO}_{3}: 357.1461$.

Compound 5, (Pathway A). To a cold $\left(0{ }^{\circ} \mathrm{C}\right)$ solution of $4(4 \mathrm{~g}, 12.2 \mathrm{mmol})$ in $100 \mathrm{~mL}$ of $\mathrm{CHCl}_{3}$ were added portion wise $6 \mathrm{~g}$ palmitic anhydride $(12.1 \mathrm{mmol})$ and $1.6 \mathrm{~g}$ DMAP $(13.1 \mathrm{mmol})$. The resulting solution was allowed to return to room temperature and left under vigorous stirring at r.t. for $48 \mathrm{~h}$. The solution was cooled down to $0{ }^{\circ} \mathrm{C}$ (ice bath) and $100 \mathrm{~mL}$ of saturated $\mathrm{NaHCO}_{3}$ were slowly added until the excess of palmitic anhydride was hydrolyzed. The phases were separated, and the organic layers were washed with brine $(4 \times 50 \mathrm{~mL})$ and dried over dry $\mathrm{Na}_{2} \mathrm{SO}_{4}$. The crude material obtained after evaporation of the solvent was purified over freshly activated $\mathrm{SiO}_{2}$ with PE:EtOAc (10:0 to 8:2 v/v) yielding 5 as a viscous oil (4.96 g, 55\%). $\mathrm{R}_{\mathrm{f}}$ (PE/EtOAc 3:1) 0.74. ${ }^{1} \mathrm{H}$ NMR $\left(300 \mathrm{MHz}, \mathrm{CDCl}_{3}\right): \delta \mathrm{H}=7.44-7.39(\mathrm{~m}, 5 \mathrm{H}, 1 \times \mathrm{Ph}), 7.33-7.20(\mathrm{~m}, 10 \mathrm{H}, 2 \times \mathrm{Ph}), 4.22-4.08(\mathrm{~m}, 2 \mathrm{H}$, $\left.\mathrm{C}(1) \mathrm{H}_{2}\right), 3.92-3.73(\mathrm{~m}, 1 \mathrm{H}, \mathrm{C}(1) \mathrm{H}), 3.21\left(\mathrm{~d}, J=5.4 \mathrm{~Hz}, 2 \mathrm{H}, \mathrm{C}(3) \mathrm{H}_{2}\right), 2.45(\mathrm{~s}, 1 \mathrm{H}, \mathrm{OH}), 2.26(\mathrm{t}, J=7.4 \mathrm{~Hz}, 2 \mathrm{H}$, $\left.\mathrm{CH}_{2} \mathrm{CH}_{2} \mathrm{COOR}\right), 1.62-1.41\left(\mathrm{~m}, 2 \mathrm{H}, \mathrm{CH}_{2} \mathrm{CH}_{2} \mathrm{COOR}\right), 1.25\left(\mathrm{~s}, 24 \mathrm{H}, 12 \times \mathrm{CH}_{2}\right), 0.87\left(\mathrm{t}, \mathrm{J}=6.7 \mathrm{~Hz}, 3 \mathrm{H}, \mathrm{CH}_{3}\right) .{ }^{13} \mathrm{C}$ NMR: $\delta_{C}=14.3\left(\mathrm{CH}_{3}\right), 22.9\left(\mathrm{CH}_{2}\right), 25.1\left(\mathrm{CH}_{2}\right), 29.3\left(\mathrm{CH}_{2}\right), 29.5\left(\mathrm{CH}_{2}\right), 29.6\left(\mathrm{CH}_{2}\right), 29.7\left(\mathrm{CH}_{2}\right), 29.8-29.9($ series of $\left.\mathrm{CH}_{2}\right), 31.2\left(\mathrm{CH}_{2}\right), 34.4\left(\mathrm{CH}_{2}\right), 64.4(\mathrm{C} 3), 65.8(\mathrm{C} 2), 69.1(\mathrm{C} 1)$ 87.1 (CqAr), 126.9 (CHAr) 127.7(CHAr) 128.4 (CHAr), $143.8\left(\mathrm{OC}(\mathrm{Ph})_{3}\right), 173.8(\mathrm{C}=\mathrm{O}) ;[\alpha]_{\mathrm{D}}^{25}=0.00\left(\mathrm{c} 0.1, \mathrm{CHCl}_{3}\right)$. 
Compound 6a (Pathway A). $1.96 \mathrm{~g}$ of $5(5.85 \mathrm{mmol})$ were dissolved in cold $\mathrm{CHCl}_{3}\left(50 \mathrm{~mL}, 0{ }^{\circ} \mathrm{C}\right)$ together with DMAP $(0.8 \mathrm{~g}, 6.44 \mathrm{mmol})$ and oleic acid $(3.18 \mathrm{~g}, 6.44 \mathrm{mmol})$. The resulting solution was slowly warmed to r.t. and the conversion of 5 into 6a was monitored periodically by TLC (PE:EtOAc 4:1 v/v). The starting material 5 was consumed after $16 \mathrm{~h}$. To the cold mixture, $50 \mathrm{~mL}$ of a solution of $\mathrm{NaHCO}_{3}(3 \% \mathrm{w} / \mathrm{w}$ in water) were slowly added and the biphasic mixtures was stirred for $30 \mathrm{~min}$ until it went back to r.t. The organic layer was extracted by adding extra volumes of $\mathrm{CHCl}_{3}(3 \times 20 \mathrm{~mL})$ and the combined organic layers were washed with saturated solutions of citric acid $(\mathrm{pH} 6,2 \times 50 \mathrm{~mL}), \mathrm{NaHCO}_{3}(3 \times 25 \mathrm{~mL})$ and brine $(3 \times 50 \mathrm{~mL})$ and dried over $\mathrm{Na}_{2} \mathrm{SO}_{4}$. The crude material obtained after evaporation of the solvent was purified over freshly activated $\mathrm{SiO}_{2}$ eluting with PE:EtOAc (4:1 to 3:1 v/v) yielding 6a as white wax (1.57 g, 55\%). ${ }^{1} \mathrm{H} \mathrm{NMR}\left(300 \mathrm{MHz}, \mathrm{CDCl}_{3}\right): \delta_{\mathrm{H}}=7.43-7.40(\mathrm{~m}$, $5 \mathrm{H}, 1 \times \mathrm{Ph}), 7.33-7.18(\mathrm{~m}, 10 \mathrm{H}, 2 \times \mathrm{Ph}), 5.39-5.29(\mathrm{~m}, \mathrm{~s}, 1 \times \mathrm{Z}-\mathrm{CH}=\mathrm{CH}), 5.28-5.20(\mathrm{~m}, 1 \mathrm{H}, \mathrm{C}(2) \mathrm{H}), 4.34(\mathrm{dd}$, $J=11.8,3.8 \mathrm{~Hz}, 1 \mathrm{H}, \mathrm{C}(1) \mathrm{Hb}),(\mathrm{dd}, J=11.8,6.6 \mathrm{~Hz}, 1 \mathrm{H}, \mathrm{C}(1) \mathrm{Ha}), 3.28-3.17\left(\mathrm{~m}, 2 \mathrm{H}, \mathrm{C}(3) \mathrm{H}_{2}\right), 2.33(\mathrm{t}, J=7.5 \mathrm{~Hz}, 2 \mathrm{H}$, $\left.1 \times \mathrm{CH}_{2} \mathrm{COOR}\right) 2.22\left(\mathrm{t}, J=7.5 \mathrm{~Hz}, 2 \mathrm{H}, 1 \times \mathrm{CH}_{2} \mathrm{COOR}\right), 2.10-1.80\left(\mathrm{~m}, 4 \mathrm{H}, 2 \times \mathrm{CH}_{2}-\mathrm{CH}=\mathrm{CH}-\mathrm{CH}_{2}\right), 1.71-1.47(\mathrm{~m}$, $\left.4 \mathrm{H}, 2 \times \mathrm{CH}_{2} \mathrm{CH}_{2} \mathrm{COOR}\right), 1.25\left(\mathrm{~s}, 42 \mathrm{H}, 21 \times \mathrm{CH}_{2}\right), 0.95-0.79(\mathrm{~m}$, superimposition of $2 \times \mathrm{t}$, apparent $J=7.0 \mathrm{~Hz}, 6 \mathrm{H}$, $\left.2 \times \mathrm{CH}_{3}\right) .{ }^{13} \mathrm{C}$ NMR $\left(75 \mathrm{MHz}, \mathrm{CDCl}_{3}\right): \delta_{\mathrm{C}}=14.3\left(\mathrm{CH}_{3}\right), 22.9\left(\mathrm{CH}_{2}\right), 25.1\left(\mathrm{CH}_{2}\right), 25.2\left(\mathrm{CH}_{2}\right), 27.4\left(\mathrm{CH}_{2}\right), 27.5\left(\mathrm{CH}_{2}\right)$, 29.3-29.7 (series of $\left.\mathrm{CH}_{2}\right)$, $32.1\left(\mathrm{CH}_{2}\right), 32.2\left(\mathrm{CH}_{2}\right), 62.4(\mathrm{C} 3), 63.0(\mathrm{C} 1), 70.6(\mathrm{C} 2), 86.9(\mathrm{CqAr}), 127.3(\mathrm{CH}), 128.1$ $(\mathrm{CH}), 129.9(\mathrm{CH}), 130.2(\mathrm{CH}), 129.9(\mathrm{Z}-\mathrm{CH}=\mathrm{CH}), 130.2(\mathrm{Z}-\mathrm{CH}=\mathrm{CH}), 143.2\left(\mathrm{OC}(\mathrm{Ph})_{3}\right), 173.2(\mathrm{C}=\mathrm{O}), 173.6(\mathrm{C}=\mathrm{O})$. $[\alpha]_{\mathrm{D}}{ }^{25}=0.00\left(\mathrm{c} 0.1, \mathrm{CHCl}_{3}\right)$.

Compound 6a (Pathway B). To a cold solution $\left(0^{\circ} \mathrm{C}\right)$ prepared by dissolving $5(1.6 \mathrm{~g}, 2.6 \mathrm{mmol})$ and DMAP $(0.4 \mathrm{~g}, 3.3 \mathrm{mmol})$ in $10 \mathrm{~mL}$ anhydrous $\mathrm{CHCl}_{3}$, were slowly added by using a syringe pump $1.0 \mathrm{~g}$ oleoyl chloride $(3.3 \mathrm{mmol})$ and the resulting solution was kept in the dark and under stirring for $18 \mathrm{~h}$ at r.t. After consumption of starting material 5 (TLC monitoring), the solution was cooled with an ice bath and $25 \mathrm{~mL}$ of saturated $\mathrm{NaHCO}_{3}$ solution were added. Organic layers were separated and then washed with additional saturated $\mathrm{NaHCO}_{3}$ solution $(2 \times 25 \mathrm{~mL})$ and with brine $(3 \times 25 \mathrm{~mL})$ and dried over $\mathrm{Na}_{2} \mathrm{SO}_{4}$. The crude material obtained after evaporation of the solvent was purified over freshly activated $\mathrm{SiO}_{2}$ with PE:EtOAc (10:0 to 9:1, v/v) yielding 6a as a white wax $(1.60 \mathrm{~g}, 73 \%) . \mathrm{R}_{\mathrm{f}}(\mathrm{PE} / \mathrm{EtOAc} 9: 1)$ 0.75. Spectroscopic data were in agreement with those recorded for the compound obtained in route $\mathrm{A}$.

\section{Appendix A.3.1. Synthesis of Compounds 6b-6d}

General method. To a stirred solution of 4 in $25-50 \mathrm{~mL} \mathrm{CHCl}$ were added equimolar amounts of the corresponding acyl chlorides: oleoyl (for $\mathbf{6 b}$ ), palmitoyl (for $\mathbf{6 c}$ ) or myristoyl (for $\mathbf{6 d}$ ) and DMAP (0.4 mol eq.). The resulting solutions were stirred overnight at r.t. The excess of acyl chlorides was decomposed by addition of $50 \mathrm{~mL} \mathrm{NaHCO}_{3}(0.4 \mathrm{M})$ and the resulting biphasic solutions were stirred for $15 \mathrm{~min}$. The biphasic solutions were extracted with $\mathrm{CHCl}_{3}(2 \times 50 \mathrm{~mL})$, and the combined organic phases were washed with $2 \times 10 \mathrm{~mL}$ of brine and dried over $\mathrm{Na}_{2} \mathrm{SO}_{4}$. Evaporation of the solvent followed by chromatography over freshly activated $\mathrm{SiO}_{2}$ with $\mathrm{CHCl}_{3}$ gave the wished compounds $\mathbf{6} \mathbf{b}$ and $\mathbf{6 c}$. Product $\mathbf{6} \mathbf{d}$ was not isolated, and the deprotection was carried out on crude mixture.

6b. White solid. $\mathrm{R}_{\mathrm{f}}$ (hexane/EtOAc 4:1) $0.36 ;{ }^{1} \mathrm{H}$ NMR $\left(300 \mathrm{MHz}, \mathrm{CDCl}_{3}\right): \delta_{\mathrm{H}}=7.40-7.11(\mathrm{~m}, 15 \mathrm{H}, 3 \times \mathrm{Ph})$, $5.27(\mathrm{~m}, 4 \mathrm{H}, 2 \times \mathrm{Z}-\mathrm{CH}=\mathrm{CH}), 5.21-5.17(\mathrm{~m}, 1 \mathrm{H}, \mathrm{C}(2) \mathrm{H}), 4.33-4.01\left(\mathrm{~m}, 2 \mathrm{H}, \mathrm{C}(1) \mathrm{H}_{2}\right), 3.16\left(\mathrm{~m}, 2 \mathrm{H}, \mathrm{C}(3) \mathrm{H}_{2}\right), 2.34-2.21$ $\left(\mathrm{m}, 4 \mathrm{H}, 2 \times \mathrm{CH}_{2} \mathrm{COOR}\right), 2.02-1.85\left(\mathrm{~m}, 8 \mathrm{H}, 2 \times \mathrm{CH}_{2}-\mathrm{CH}=\mathrm{CH}-\mathrm{CH}_{2}\right), 1.62-1.42\left(2 \times \mathrm{br}, 4 \mathrm{H}, 2 \times \mathrm{CH}_{2} \mathrm{CH}_{2} \mathrm{COOR}\right)$, $1.21\left(\mathrm{~s}, 40 \mathrm{H}, 20 \times \mathrm{CH}_{2}\right), 0.81\left(\mathrm{t}, J=8.0 \mathrm{~Hz}, 6 \mathrm{H}, 2 \times \mathrm{CH}_{3}\right) .{ }^{13} \mathrm{C} \mathrm{NMR}\left(75 \mathrm{MHz}, \mathrm{CDCl}_{3}\right): \delta_{\mathrm{C}}=14.3\left(\mathrm{CH}_{3}\right), 22.9\left(\mathrm{CH}_{2}\right)$, $25.0\left(\mathrm{CH}_{2}\right), 25.3\left(\mathrm{CH}_{2}\right), 27.3\left(\mathrm{CH}_{2}\right), 27.4\left(\mathrm{CH}_{2}\right), 29.4-29.9\left(\right.$ series of $\left.\mathrm{CH}_{2}\right), 32.1\left(\mathrm{CH}_{2}\right), 34.3\left(\mathrm{CH}_{2}\right), 34.4 .7\left(\mathrm{CH}_{2}\right)$, $62.2(\mathrm{C} 3), 62.0(\mathrm{C} 1), 72.2(\mathrm{C} 2), 86.9(\mathrm{CqAr}), 127.1(\mathrm{CH}), 127.4(\mathrm{CH}), 127.9(\mathrm{CH}), 128.0(\mathrm{CH}), 128.1(\mathrm{CH}), 128.7(\mathrm{CH})$, $128.8(\mathrm{CH}), 129.9(\mathrm{Z}-\mathrm{CH}=\mathrm{CH}), 130.4(\mathrm{Z}-\mathrm{CH}=\mathrm{CH}), 143.2\left(\mathrm{OC}(\mathrm{Ph})_{3}\right), 173.5(\mathrm{C}=\mathrm{O}), 173.9(\mathrm{C}=\mathrm{O}) .[\alpha]_{\mathrm{D}}^{25}=0.00(\mathrm{c} 0.1$, $\left.\mathrm{CHCl}_{3}\right)$. ESI-MS $m / z 885$ as $\mathrm{M}+\mathrm{Na}^{+}$.

6c. White wax. $\mathrm{R}_{\mathrm{f}}$ (PE:EtOAc 4:1) 0.50; ${ }^{1} \mathrm{H}$ NMR $\left(400 \mathrm{MHz}, \mathrm{CDCl}_{3}\right): \delta_{\mathrm{H}}=7.45-7.39(\mathrm{~m}, 5 \mathrm{H}, 1 \times \mathrm{Ph}), 7.33-7.20$ $(\mathrm{m}, 10 \mathrm{H}, 2 \times \mathrm{Ph}), 5.30-5.22(\mathrm{~m}, 1 \mathrm{H}, \mathrm{C}(2) \mathrm{H}), 4.34\left(\mathrm{dd}, J=11.8,3.7 \mathrm{~Hz}, 1 \mathrm{H}, \mathrm{C}(1) \mathrm{H}_{2}\right), 4.23(\mathrm{dd}, J=11.8,6.7 \mathrm{~Hz}, 1 \mathrm{H}$, $\left.\mathrm{C}(3) \mathrm{H}_{2}\right), 3.26-3.19\left(\mathrm{~m}, 4 \mathrm{H}, 2 \times \mathrm{CH}_{2} \mathrm{CH}_{2} \mathrm{COOR}\right), 2.33\left(\mathrm{t}, J=9.0 \mathrm{~Hz}, 2 \mathrm{H}, 1 \times \mathrm{CH}_{2} \mathrm{CH}_{2} \mathrm{COOR}\right), 2.23(\mathrm{t}, J=9.0 \mathrm{~Hz}, 2 \mathrm{H}$, $\left.1 \times \mathrm{CH}_{2} \mathrm{CH}_{2} \mathrm{COOR}\right), 1.69-1.50\left(\mathrm{~m}, 4 \mathrm{H}, 2 \times \mathrm{CH}_{2} \mathrm{CH}_{3}\right), 1.25,\left(\mathrm{~s} 44 \mathrm{H}, 22 \times \mathrm{CH}_{2}\right), 0.88\left(\mathrm{t}, \mathrm{J}=9.0 \mathrm{~Hz}, 6 \mathrm{H}, 2 \times \mathrm{CH}_{3}\right)$; ${ }^{13} \mathrm{C}(100 \mathrm{MHz}) \delta_{\mathrm{C}}=14.2\left(\mathrm{CH}_{3}\right), 22.9\left(\mathrm{CH}_{2}\right), 24.4\left(\mathrm{CH}_{2}-\mathrm{COOR}\right), 24.8\left(\mathrm{CH}_{2} \mathrm{CH}_{2} \mathrm{COOR}\right), 25.1\left(\mathrm{CH}_{2}\right), 25.2\left(\mathrm{CH}_{2}\right)$, $29.1\left(\mathrm{CH}_{2}\right), 29.2\left(\mathrm{CH}_{2}\right), 29.3\left(\mathrm{CH}_{2}\right), 29.2\left(\mathrm{CH}_{2}\right), 29.4\left(\mathrm{CH}_{2}\right), 29.7\left(\mathrm{CH}_{2}\right), 29.8-30.0\left(\right.$ series of $\left.\mathrm{CH}_{2}\right), 63.1(\mathrm{C} 3), 62.7(\mathrm{C} 1)$, $70.5(\mathrm{C} 2), 86.9(\mathrm{CqAr}), 122.2(\mathrm{Ar}) 127.9(\mathrm{Ar}), 128.6(\mathrm{Ar}), 144.8\left(\mathrm{C}\left(\mathrm{Ph}_{3}\right)\right), 173.2(\mathrm{C}=\mathrm{O}), 173.6(\mathrm{C}=\mathrm{O}) ;[\alpha]_{\mathrm{D}}{ }^{25}=0.00$ (c $0.1, \mathrm{CHCl}_{3}$ ); $\mathrm{HRMS} m / z$ : [M] $]^{+}$calcd. for $\mathrm{C}_{54} \mathrm{H}_{82} \mathrm{O}_{5}$ : 819.6162, found $\mathrm{C}_{54} \mathrm{H}_{82} \mathrm{NaO}_{5}$ : 833.6054.

6d. The crude mixture containing $6 \mathbf{d}$ was directly treated for deprotection. ESI-MS $\mathrm{m} / \mathrm{z} 777 \mathrm{as} \mathrm{M}+\mathrm{Na}^{+}$;

Compound 8 (Pathway B). $3.0 \mathrm{~g}$ of $\alpha, \beta$-isopropylidene-DL-glycerol $(3 \mathbf{b}, 22.7 \mathrm{mmol})$ were dissolved in dry $\mathrm{CH}_{2} \mathrm{Cl}_{2}(80.0 \mathrm{~mL})$ and the solution was cooled to $0{ }^{\circ} \mathrm{C}$ using a thermostatic bath. Palmitoyl chloride $(7.80 \mathrm{~g}$, $28.4 \mathrm{mmol})$ was added together with $\operatorname{DMAP}(3.5 \mathrm{~g}, 28.4 \mathrm{mmol})$ and the resulting solution was left under vigorous stirring at r.t. for $18 \mathrm{~h}$. $25 \mathrm{~mL}$ of saturated $\mathrm{NaHCO}_{3}$ were added dropwise until the excess of palmitoyl chloride was consumed. The phases were separated, and the organic layers were washed with brine $(3 \times 25 \mathrm{~mL})$ and dried over dry $\mathrm{Na}_{2} \mathrm{SO}_{4}$. The crude material obtained after evaporation of the solvent was purified over freshly activated $\mathrm{SiO}_{2}$ with Cy: EtOAc (9:1 v/v) yielding 8 as a viscous oil $(5.23 \mathrm{~g}, 62 \%)$. Rf (Cy/EtOAc 1:1) 0.70. ${ }^{1} \mathrm{H} \mathrm{NMR}(300 \mathrm{MHz}$, $\left.\mathrm{CDCl}_{3}\right): \delta_{\mathrm{H}}=4.35-4.30(\mathrm{~m}, \mathrm{C}(4)), 4.20-4.01(\mathrm{~m}, 3 \mathrm{H}, \mathrm{RCOOCHHb}, \mathrm{RCOOCHaH}, \mathrm{C}(5) \mathrm{Hb}), 3.72(\mathrm{dd}, J=8.4,6.2 \mathrm{~Hz}$, $1 \mathrm{H} ; \mathrm{C}(5) \mathrm{Ha}), 2.32\left(\mathrm{t}, J=6.0 \mathrm{~Hz}, 2 \mathrm{H}, \mathrm{CH}_{2} \mathrm{COOR}\right), 2.03(\mathrm{~s}, 1 \mathrm{H}), 1.69-1.51\left(\mathrm{~m}, 2 \mathrm{H}_{1} \mathrm{CH}_{2} \mathrm{CH}_{2} \mathrm{COOR}\right), 1.42,1.36(2 \times \mathrm{s}$, $\left.6 \mathrm{H},\left(\mathrm{CH}_{3}\right)_{2} \mathrm{C}(2)\right), 1.24\left(\mathrm{~m}, 20 \mathrm{H}, 10 \times \mathrm{CH}_{2}\right), 0.86\left(\mathrm{t}, J=8.0 \mathrm{~Hz}, 3 \mathrm{H}, \mathrm{CH}_{3}\right) .{ }^{13} \mathrm{C} \mathrm{NMR:}_{\mathrm{C}}=14.1\left(\mathrm{CH}_{3}\right), 22.7\left(\mathrm{CH}_{2}\right)$, $24.9\left(\mathrm{CH}_{2}\right), 25.4\left(\mathrm{CH}_{2}\right), 26.7\left(\mathrm{CH}_{2}\right), 29.8-29.9\left(\right.$ series of $\left.\mathrm{CH}_{2}\right), 31.9\left(\mathrm{CH}_{2}\right), 34.1\left(\mathrm{CH}_{2}\right), 64.5\left(\mathrm{COOCH}_{2}\right), 66.3(\mathrm{C} 5)$, $76.6(\mathrm{C} 4), 109.8(\mathrm{C} 2), 173.6(\mathrm{C}=\mathrm{O}) ;[\alpha]_{\mathrm{D}}{ }^{25}=0.00\left(\mathrm{c} 0.1, \mathrm{CHCl}_{3}\right)$. 
Compound 9. (Pathway B). $1.8 \mathrm{~g}$ of $8(4.9 \mathrm{mmol})$ were dissolved in $40 \mathrm{~mL}$ of dry $\mathrm{CH}_{2} \mathrm{Cl}_{2}$ and $5.8 \mathrm{~g}$ of Amberlyst ${ }^{\circledR} 15 \mathrm{H}^{+}$resin were added. The suspension was stirred vigorously at r.t. until complete disappearing of the starting material was observed $(4 \mathrm{~h})$. The solution was filtered over a pad of Celite and the solvent evaporated. $1.6 \mathrm{~g}$ of $9(>99.0 \%)$ were recovered as a yellowish oil. $\mathrm{R}_{\mathrm{f}}(\mathrm{PE} / \mathrm{EtOAc} 1: 1)$ 0.47. ${ }^{1} \mathrm{H} \mathrm{NMR}\left(300 \mathrm{MHz}, \mathrm{CDCl}_{3}\right)$ : $\delta_{\mathrm{H}}=4.23-4.09\left(\mathrm{~m}, 2 \mathrm{H}, \mathrm{C}(1) \mathrm{H}_{2}\right), 3.92-3.86(\mathrm{~m}, 1 \mathrm{H}, \mathrm{C}(2) \mathrm{H}), 3.69(\mathrm{dd}, J=11.5,3.8 \mathrm{~Hz}, 1 \mathrm{H}, \mathrm{C}(3) \mathrm{Hb}), 3.58(\mathrm{dd}$, $J=11.5,8.9 \mathrm{~Hz}, 1 \mathrm{H}, \mathrm{C}(3) \mathrm{Ha}), 2.34\left(\mathrm{t}, J=7.6 \mathrm{~Hz}, 2 \mathrm{H}, \mathrm{CH}_{2} \mathrm{COOR}\right), 1.69-1.52\left(\mathrm{~m}, 2 \mathrm{H}, \mathrm{CH}_{2} \mathrm{CH}_{2} \mathrm{COOR}\right), 1.24,(\mathrm{~s}, 24 \mathrm{H}$, $\left.12 \times \mathrm{CH}_{2}\right), 0.87\left(\mathrm{t}, J=6.7 \mathrm{~Hz}, 3 \mathrm{H}, \mathrm{CH}_{3}\right) .{ }^{13} \mathrm{C} \mathrm{NMR:} \delta_{\mathrm{C}}=14.1\left(\mathrm{CH}_{3}\right), 22.7\left(\mathrm{CH}_{2}\right), 24.9\left(\mathrm{CH}_{2}\right), 25.4\left(\mathrm{CH}_{2}\right), 29.1-29.7$ (series of $\left.\mathrm{CH}_{2}\right), 31.9\left(\mathrm{CH}_{2}\right), 34.2\left(\mathrm{CH}_{2}\right), 63.1(\mathrm{C} 1), 64.9(\mathrm{C} 2), 76.6(\mathrm{C} 3), 174.2(\mathrm{C}=\mathrm{O}) ;[\alpha]_{\mathrm{D}}{ }^{25}=0.00\left(\mathrm{c} 0.1, \mathrm{CHCl}_{3}\right)$.

Appendix A.3.2. Deprotection of compounds 6a-6d into 7a-7d: Pathways A and B

General method for deprotection of $\mathbf{6 a}-\mathbf{6} \mathbf{d}$ into $7 \mathbf{a}-7 \mathbf{d}$ obtained from routes A and B.

A mixture of $\mathrm{CHCl}_{3}-\mathrm{MeOH}(100 \mathrm{~mL}, 1: 1 \mathrm{v} / \mathrm{v})$ containing $44 \mu \mathrm{L}$ of concentrated $\mathrm{HCl}(12 \mathrm{~N}, 37 \%)$ was added dropwise to a $\mathrm{CHCl}_{3}-\mathrm{MeOH}$ solution $(100 \mathrm{~mL}, 1: 1 \mathrm{v} / \mathrm{v})$ of $8 \mathbf{a}-\mathbf{d}$ during $6 \mathrm{~h}$ at $0{ }^{\circ} \mathrm{C}$. The obtained clear solution was left stirring at $4{ }^{\circ} \mathrm{C}$ overnight. A saturated solution of $\mathrm{NaHCO}_{3}$ was then added slowly $(15 \mathrm{~min})$ and the resulting heterogeneous biphasic solution was stirred up to room temperature. The resulting solutions were extracted with $\mathrm{CHCl}_{3}(3 \times 250 \mathrm{~mL})$, and the combined organic phases was washed with brine $(3 \times 100 \mathrm{~mL})$ and dried over $\mathrm{Na}_{2} \mathrm{SO}_{4}$. Evaporation of the solvent followed by chromatography over freshly activated $\mathrm{SiO}_{2}$ with $\mathrm{CHCl}_{3}$ gave products $\mathbf{7 a - 7 d}$ as pale-yellow oils. Yields are reported in Table A1.

Table A1. Data for the preparation of rac diacyl glycerols $\mathbf{6 b}-\mathbf{6 d}$ using $\mathbf{4}$ as common building block.

\begin{tabular}{cccccccc}
\hline Entry & Acylation Scale & Yield & Entry & Deprotection & Scale $^{\mathbf{1}}$ & Yield \\
\hline & & & & 4 & $\mathbf{6 a} \rightarrow \mathbf{7 a}$ & $1.6 \mathrm{~g}$ & $45 \%$ \\
1 & $\mathbf{4} \rightarrow \mathbf{6 b}$ & $2.2 \mathrm{~g}$ & $58 \%$ & 5 & $\mathbf{6 b} \rightarrow \mathbf{7 b}$ & $700 \mathrm{mg}$ & $50 \%$ \\
2 & $\mathbf{4 \rightarrow 6 \mathbf { c }}$ & $1.0 \mathrm{~g}$ & $31 \%$ & 6 & $\mathbf{6 c \rightarrow 7 c}$ & $450 \mathrm{mg}$ & $89 \%$ \\
3 & $4 \rightarrow \mathbf{6 d}$ & $1.0 \mathrm{~g}$ & - & 7 & $\mathbf{6 d} \rightarrow \mathbf{7 d}$ & $910 \mathrm{mg}^{2}$ & $60 \%$ \\
\hline
\end{tabular}

7a. $\mathrm{R}_{\mathrm{f}}(9: 1 \mathrm{PE} / \mathrm{EtOAc}) 0.15 ;{ }^{1} \mathrm{H}$ NMR $\left(300 \mathrm{MHz}, \mathrm{CDCl}_{3}\right): \delta_{\mathrm{H}}=5.41-5.28(\mathrm{~m}, 2 \mathrm{H}, \mathrm{Z}-\mathrm{CH}=\mathrm{CH}), 5.15-4.98(\mathrm{~m}$, $1 \mathrm{H}, \mathrm{C}(2) \mathrm{H}), 4.32(\mathrm{dd}, J=11.9,4.5 \mathrm{~Hz}, 1 \mathrm{H}, \mathrm{C}(1) \mathrm{Hb}), 4.22(\mathrm{dd}, J=11.9,5.7 \mathrm{~Hz}, 1 \mathrm{H}, \mathrm{C}(1) \mathrm{Ha}), 3.78-3.56(\mathrm{~m}, 2 \mathrm{H}$, $\left.\mathrm{C}(3) \mathrm{H}_{2}\right), 2.32\left(\mathrm{dd}, J=14.8,7.3 \mathrm{~Hz}, 4 \mathrm{H}, 2 \times \mathrm{CH}_{2} \mathrm{COOR}\right), 2.08-1.92\left(\mathrm{~m}, 4 \mathrm{H}, 2 \times \mathrm{CH}_{2}-\mathrm{CH}=\mathrm{CH}-\mathrm{CH}_{2}\right), 1.70-1.55$ $\left(\mathrm{m}, 4 \mathrm{H}, 2 \mathrm{CH}_{2} \mathrm{CH}_{2} \mathrm{COOR}\right), 1.30,1.26\left(2 \times \mathrm{br}, 38 \mathrm{H}, 19 \times \mathrm{CH}_{2}\right), 0.96-0.76(\mathrm{~m}$, superimposition of $2 \times \mathrm{t}$, apparent $\left.J=6.8 \mathrm{~Hz}, 6 \mathrm{H}, 2 \times \mathrm{CH}_{3}\right) .{ }^{13} \mathrm{C} \mathrm{NMR}\left(75 \mathrm{MHz}, \mathrm{CDCl}_{3}\right): \delta_{\mathrm{C}}=14.3\left(\mathrm{CH}_{3}\right), 22.9\left(\mathrm{CH}_{2}\right), 25.1\left(\mathrm{CH}_{2}\right), 27.3\left(\mathrm{CH}_{2}\right), 27.4$ $\left(\mathrm{CH}_{2}\right), 29.3\left(\mathrm{CH}_{2}\right), 29.5-29.9\left(\right.$ series of $\left.\mathrm{CH}_{2}\right), 30.0\left(\mathrm{CH}_{2}\right), 32.1\left(\mathrm{CH}_{2}\right), 34.3\left(\mathrm{CH}_{2}\right), 61.7(\mathrm{C} 3), 62.2(\mathrm{C} 1), 72.3(\mathrm{C} 2), 129.9$ $(\mathrm{Z}-\mathrm{CH}=\mathrm{CH}), 130.2(\mathrm{Z}-\mathrm{CH}=\mathrm{CH}), 174.0(\mathrm{C}=\mathrm{O}), 176.6(\mathrm{C}=\mathrm{O}) ;[\alpha]_{\mathrm{D}}^{25}=0.00\left(\mathrm{c} 0.1, \mathrm{CHCl}_{3}\right)$.

7b. $\mathrm{R}_{\mathrm{f}}\left(2: 1\right.$ hexane/EtOAc) $0.30 ;{ }^{1} \mathrm{H}$ NMR $\left(300 \mathrm{MHz}, \mathrm{CDCl}_{3}\right): \delta_{\mathrm{H}}=5.40-5.28(\mathrm{~m}, 4 \mathrm{H}, 2 \times \mathrm{Z}-\mathrm{CH}=\mathrm{CH}), 5.08$ (quint, $1 \mathrm{H}, J=5.0 \mathrm{~Hz}, \mathrm{C}(2) \mathrm{H}), 4.31(\mathrm{dd}, J=11.9,4.6 \mathrm{~Hz}, 1 \mathrm{H}, \mathrm{C}(1) \mathrm{HHb}), 4.24(\mathrm{dd}, J=11.9,4.6 \mathrm{~Hz}, 1 \mathrm{H}, \mathrm{C}(1) \mathrm{HaH})$, $3.74(\mathrm{dd}, J=12.2,4.7 \mathrm{~Hz}, 1 \mathrm{H}, \mathrm{C}(3) \mathrm{HHb}), 3.72(\mathrm{dd}, J=12.2,4.7 \mathrm{~Hz}, 1 \mathrm{H}, \mathrm{C}(3) \mathrm{HaH}), 2.39-2.37(2 \times \mathrm{t}, J=7.5 \mathrm{~Hz}$ $\left.4 \mathrm{H}, 2 \times \mathrm{CH}_{2} \mathrm{COOR}\right), 2.08-1.90\left(\mathrm{~m}, 8 \mathrm{H}, 2 \times \mathrm{CH}_{2}-\mathrm{CH}=\mathrm{CH}-\mathrm{CH}_{2}\right), 1.67-1.56\left(\mathrm{~m}, 4 \mathrm{H}, 2 \times \mathrm{CH}_{2} \mathrm{CH}_{2} \mathrm{COOR}\right), 1.30,1.26$ $\left(2 \times \mathrm{br}, 40 \mathrm{H}, 20 \times \mathrm{CH}_{2}\right), 0.87\left(\mathrm{t}, J=6.8 \mathrm{~Hz}, 6 \mathrm{H}, 2 \times \mathrm{CH}_{3}\right) .{ }^{13} \mathrm{C} \mathrm{NMR}\left(75 \mathrm{MHz}, \mathrm{CDCl}_{3}\right): \delta_{\mathrm{C}}=14.1\left(\mathrm{CH}_{3}\right), 22.1\left(\mathrm{CH}_{2}\right)$, 24.8 $\left(\mathrm{CH}_{2}\right), 24.9\left(\mathrm{CH}_{2}\right), 25.6\left(\mathrm{CH}_{2}\right), 27.0\left(\mathrm{CH}_{2}\right), 27.1\left(\mathrm{CH}_{2}\right), 27.2\left(\mathrm{CH}_{2}\right), 29.0-29.2\left(4 \times \mathrm{CH}_{2}\right), 29.3\left(\mathrm{CH}_{2}\right), 29.5\left(\mathrm{CH}_{2}\right)$, $29.7\left(\mathrm{CH}_{2}\right), 29.8\left(\mathrm{CH}_{2}\right), 31.9\left(\mathrm{CH}_{2}\right), 34.0\left(\mathrm{CH}_{2}\right), 34.3\left(\mathrm{CH}_{2}\right), 61.5(\mathrm{C} 3), 62.0(\mathrm{C} 1), 72.2(\mathrm{C} 2), 129.8(\mathrm{Z}-\mathrm{CH}=\mathrm{CH}), 130.0$ $(\mathrm{Z}-\mathrm{CH}=\mathrm{CH}), 173.5(\mathrm{C}=\mathrm{O}), 173.9(\mathrm{C}=\mathrm{O}) ;[\alpha]_{\mathrm{D}}{ }^{25}=0.00\left(\mathrm{c} 0.1, \mathrm{CHCl}_{3}\right) ; \mathrm{ESI}-\mathrm{MS} \mathrm{m} / \mathrm{z} 643$ as $[\mathrm{M}+\mathrm{Na}]^{+} ; \mathrm{HRMS} m / z:[\mathrm{M}]^{+}$ calcd. for $\mathrm{C}_{39} \mathrm{H}_{72} \mathrm{NO}_{5}$ : 634.5410, found $\mathrm{C}_{39} \mathrm{H}_{72} \mathrm{NO}_{5}$ : 634.5272 .

7c. $\mathrm{R}_{\mathrm{f}}(\mathrm{PE} / \mathrm{EtOAc} 7: 1) 0.30 ;{ }^{1} \mathrm{H}$ NMR $\left(400 \mathrm{MHz}, \mathrm{CDCl}_{3}\right): \delta \mathrm{H}=5.13-5.03(\mathrm{~m}, 1 \mathrm{H}, \mathrm{C}(2) \mathrm{H}), 4.31(\mathrm{dd}, J=11.9$, $4.4 \mathrm{~Hz}, 1 \mathrm{H}, \mathrm{C}(1) \mathrm{HHb}), 4.22(\mathrm{dd}, J=11.9,5.8 \mathrm{~Hz}, 1 \mathrm{H}, \mathrm{C}(1) \mathrm{HaH}), 3.72\left(\mathrm{~d}, J=5.0 \mathrm{~Hz}, 1 \mathrm{H}, \mathrm{C}(3) \mathrm{H}_{2}\right), 2.32(\mathrm{dd}, J=9.0$, $\left.7.6 \mathrm{~Hz}, 4 \mathrm{H}, 2 \mathrm{CH}_{2} \mathrm{COOR}\right), 1.61\left(\mathrm{dd}, J=13.1,6.8 \mathrm{~Hz}, 4 \mathrm{H}, 2 \times \mathrm{CH}_{2} \mathrm{CH}_{2} \mathrm{COOR}\right), 1.24(\mathrm{~s}, 52 \mathrm{H}, 26 \times \mathrm{CH} 2), 0.87(\mathrm{t}$, $J=6.9 \mathrm{~Hz}, 6 \mathrm{H}, 2 \times \mathrm{CH} 3) .{ }^{13} \mathrm{C} \mathrm{NMR}\left(75 \mathrm{MHz}, \mathrm{CDCl}_{3}\right): \delta_{\mathrm{C}}=14.3(\mathrm{CH} 3), 22.9\left(\mathrm{CH}_{2}\right), 25.0\left(\mathrm{CH}_{2}\right), 25.1\left(\mathrm{CH}_{2}\right), 29.3-29.9$ (series of $\left.\mathrm{CH}_{2}\right), 34.3\left(\mathrm{CH}_{2}\right), 34.5\left(\mathrm{CH}_{2}\right), 61.7(\mathrm{C} 3), 62.2(\mathrm{C} 1), 72.3(\mathrm{C} 2), 173.7(\mathrm{C}=\mathrm{O}), 174.0(\mathrm{C}=\mathrm{O}) ;[\alpha]_{\mathrm{D}}{ }^{25}=0.00(\mathrm{c} 0.1$, $\left.\mathrm{CHCl}_{3}\right)$; ESI-MS m/z 591 as $\mathrm{M}+\mathrm{Na}^{+}$;

7d. $\mathrm{R}_{\mathrm{f}}\left(2: 1\right.$ hexane/EtOAc) $0.40 ;{ }^{1} \mathrm{H} \mathrm{NMR}\left(400 \mathrm{MHz}, \mathrm{CDCl}_{3}\right): \delta_{\mathrm{H}}=5.08$ (quint, $\left.1 \mathrm{H}, J=8.2 \mathrm{~Hz}, \mathrm{C}(2) \mathrm{H}\right), 4.32$ $(\mathrm{dd}, J=11.9,4.5 \mathrm{~Hz}, 1 \mathrm{H}, \mathrm{C}(1) \mathrm{HHb}), 4.23(\mathrm{dd}, J=11.9,5.7 \mathrm{~Hz}, 1 \mathrm{H}, \mathrm{C}(1) \mathrm{HaH}), 3.73\left(\mathrm{~d}, J=4.8 \mathrm{~Hz}, 1 \mathrm{H}, \mathrm{C}(3) \mathrm{H}_{2}\right), 2.33$ $\left(\mathrm{dd}, J=15.9,8.2 \mathrm{~Hz}, 4 \mathrm{H}, 2 \times \mathrm{CH}_{2} \mathrm{COOR}\right), 2.08(\mathrm{~s}, 1 \mathrm{H},-\mathrm{OH}), 1.67-1-57\left(\mathrm{~m}, 4 \mathrm{H}, 2 \times \mathrm{CH}_{2} \mathrm{CH}_{2} \mathrm{COOR}\right), 1.25(\mathrm{~s}, 40 \mathrm{H}$, $\left.20 \times \mathrm{CH}_{2}\right), 0.87\left(\mathrm{t}, J=6.9 \mathrm{~Hz}, 6 \mathrm{H}, 2 \times \mathrm{CH}_{3}\right) .{ }^{13} \mathrm{C} \mathrm{NMR}\left(75 \mathrm{MHz}, \mathrm{CDCl}_{3}\right): \delta_{\mathrm{C}}=14.3\left(\mathrm{CH}_{3}\right), 22.9\left(\mathrm{CH}_{2}\right), 25.1\left(\mathrm{CH}_{2}\right)$, $25.2\left(\mathrm{CH}_{2}\right), 29.2\left(\mathrm{CH}_{2}\right), 29.3\left(\mathrm{CH}_{2}\right), 29.5\left(\mathrm{CH}_{2}\right), 29.6\left(\mathrm{CH}_{2}\right), 29.7\left(\mathrm{CH}_{2}\right), 29.8\left(\mathrm{CH}_{2}\right), 29.9\left(\mathrm{CH}_{2}\right), 30.0\left(\mathrm{CH}_{2}\right), 32.1$ $\left(\mathrm{CH}_{2}\right), 34.3\left(\mathrm{CH}_{2}\right), 34.5\left(\mathrm{CH}_{2}\right), 61.7(\mathrm{C} 3), 62.2(\mathrm{C} 1), 72.4(\mathrm{C} 2), 173.7(\mathrm{C}=\mathrm{O}), 174.0(\mathrm{C}=\mathrm{O}) ;[\alpha]_{\mathrm{D}}{ }^{25}=0.00\left(\mathrm{c} 0.1, \mathrm{CHCl}_{3}\right)$;

\section{Appendix A.3.3. Synthesis of Compounds 7a and (S)-(7a): Pathway C}

Compound 8 (Pathway C). $3.7 \mathrm{~g}$ of $\alpha, \beta$-isopropylidene-DL-glycerol (3b, $28.6 \mathrm{mmol})$ were dissolved in dry $\mathrm{CH}_{2} \mathrm{Cl}_{2}(75 \mathrm{~mL})$ and palmitic acid $(7.3 \mathrm{~g}, 28.6 \mathrm{mmol})$ was added. The solution was cooled to $0{ }^{\circ} \mathrm{C}$ using an ice bath, DMAP $(1.0 \mathrm{~g}, 8.6 \mathrm{mmol})$ and EDC. $\mathrm{HCl}(7.1 \mathrm{~g}, 37.2 \mathrm{mmol})$ were added together. The resulting solution was left under vigorous stirring at r.t. for $18 \mathrm{~h}$. A quantity of $150 \mathrm{~mL}$ of saturated $\mathrm{NaHCO}_{3}$ was added to quench the 
reaction. The product was then extracted with $\mathrm{CH}_{2} \mathrm{Cl}_{2}(2 \times 100 \mathrm{~mL})$. The combined organic phases were dried over anhydrous $\mathrm{MgSO}_{4}$ and the crude material obtained after evaporation of the solvent was purified over $\mathrm{SiO}_{2}$ with PE:EtOAc (99:1 to 85:15, v/v) yielding 8 as a white powder $(9.99 \mathrm{~g}, 94 \%) . \mathrm{R}_{\mathrm{f}}(\mathrm{PE} / \mathrm{EtOAc} 9: 1)$ 0.5. ${ }^{1} \mathrm{H}$ NMR $\left(300 \mathrm{MHz}, \mathrm{CDCl}_{3}\right): \delta_{\mathrm{H}}=4.33-4.27(\mathrm{~m}, 1 \mathrm{H}, \mathrm{C}(4) \mathrm{H}), 4.19-4.05(\mathrm{~m}, 3 \mathrm{H}, \mathrm{RCOOCHHb}, \mathrm{RCOOCHaH}, \mathrm{C}(5) \mathrm{Hb}), 3.74$ $(\mathrm{dd}, J=8.4,6.2 \mathrm{~Hz}, 1 \mathrm{H}, \mathrm{C}(5) \mathrm{Ha}), 2.34\left(\mathrm{t}, J=7.6 \mathrm{~Hz}, 2 \mathrm{H}, \mathrm{CH}_{2} \mathrm{COOR}\right), 1.64-1.57$ (m, $\left.2 \mathrm{H}, \mathrm{CH}_{2} \mathrm{CH}_{2} \mathrm{COOR}\right), 1.43$, $1.37\left(2 \times \mathrm{s}, 6 \mathrm{H},\left(\mathrm{CH}_{3}\right)_{2} \mathrm{C}(2)\right), 1.25\left(\mathrm{~m}, 24 \mathrm{H}, 12 \times \mathrm{CH}_{2}\right), 0.88\left(\mathrm{t}, J=6.9 \mathrm{~Hz}, 3 \mathrm{H}, \mathrm{CH}_{3}\right) .{ }^{13} \mathrm{C} \mathrm{NMR:} \delta_{\mathrm{C}}=14.1\left(\mathrm{CH}_{3}\right)$, $22.7\left(\mathrm{CH}_{2}\right), 24.9\left(\mathrm{CH}_{2}\right), 25.4\left(\mathrm{CH}_{2}\right), 26.7\left(\mathrm{CH}_{2}\right), 29.8-29.9\left(\right.$ series of $\left.\mathrm{CH}_{2}\right), 31.9\left(\mathrm{CH}_{2}\right), 34.1\left(\mathrm{CH}_{2}\right), 64.5\left(\mathrm{COOCH}_{2}\right)$, $66.3(\mathrm{C} 5), 76.6(\mathrm{C} 4), 109.8(\mathrm{C} 2), 173.6(\mathrm{C}=\mathrm{O}) ;[\alpha]_{\mathrm{D}}^{25}=0.00\left(\mathrm{c} 0.1, \mathrm{CHCl}_{3}\right)$.

Compound 9 (Pathway C). A quantity of $9.99 \mathrm{~g}$ of $8(26.9 \mathrm{mmol})$ was dissolved in a mixture of $\mathrm{AcOH} / \mathrm{H}_{2} \mathrm{O}$ $(100 / 25 \mathrm{~mL}, 4: 1 \mathrm{v} / \mathrm{v})$ and kept under vigorous stirring at $55^{\circ} \mathrm{C}$ for $2 \mathrm{~h}$. The solution was cooled to r.t. and $150 \mathrm{~mL}$ of saturated $\mathrm{NaHCO}_{3}$ were added dropwise until the solution was neutralized. The product was then extracted with ethyl acetate $(2 \times 100 \mathrm{~mL})$. The combined organic phases were washed with brine $(100 \mathrm{~mL})$ and dried over anhydrous $\mathrm{MgSO}_{4}$. The resulting solution was evaporated yielding 9 as a white powder $(8.90 \mathrm{~g}, 99 \%) .{ }^{1} \mathrm{H} \mathrm{NMR}$ $\left(300 \mathrm{MHz}, \mathrm{CDCl}_{3}\right): \delta_{\mathrm{H}}=4.23-4.11\left(\mathrm{~m}, 2 \mathrm{H}, \mathrm{C}(1) \mathrm{H}_{2}\right), 3.96-3.90(\mathrm{~m}, 1 \mathrm{H}, \mathrm{C}(2) \mathrm{H}), 3.70(\mathrm{dd}, J=11.4,3.8 \mathrm{~Hz}, 1 \mathrm{H}$, $\mathrm{C}(3) \mathrm{Hb}), 3.60(\mathrm{dd}, \mathrm{J}=11.4,5.7 \mathrm{~Hz}, 1 \mathrm{H}, \mathrm{C}(3) \mathrm{Ha}), 2.80(\mathrm{~s}, 2 \mathrm{H}, 2 \times \mathrm{OH}), 2.35\left(\mathrm{t}, J=7.4 \mathrm{~Hz}, 2 \mathrm{H}, \mathrm{CH}_{2} \mathrm{COOR}\right), 1.67-1.58$ $\left(\mathrm{m}, 2 \mathrm{H}, \mathrm{CH}_{2} \mathrm{CH}_{2} \mathrm{COOR}\right), 1.26\left(\mathrm{~m}, 24 \mathrm{H}, 12 \times \mathrm{CH}_{2}\right), 0.88\left(\mathrm{t}, J=6.6 \mathrm{~Hz}, 3 \mathrm{H}, \mathrm{CH}_{3}\right) .{ }^{13} \mathrm{C} \mathrm{NMR:} \delta_{\mathrm{C}}=14.1\left(\mathrm{CH}_{3}\right)$, $22.7\left(\mathrm{CH}_{2}\right), 24.9\left(\mathrm{CH}_{2}\right), 25.4\left(\mathrm{CH}_{2}\right), 29.1-29.7$ (series of $\left.\mathrm{CH}_{2}\right), 31.9\left(\mathrm{CH}_{2}\right), 34.2\left(\mathrm{CH}_{2}\right), 63.1(\mathrm{C} 1), 64.9(\mathrm{C} 2), 76.6(\mathrm{C} 3)$, $174.2(\mathrm{C}=\mathrm{O}) ;[\alpha]_{\mathrm{D}}^{25}=0.00\left(\mathrm{c} 0.1, \mathrm{CHCl}_{3}\right)$.

Compound 10. A quantity of $8.90 \mathrm{~g}$ of $9(26.9 \mathrm{mmol})$ was dissolved in dry $\mathrm{CH}_{2} \mathrm{Cl}_{2}(250.0 \mathrm{~mL})$ and imidazole $(2.7 \mathrm{~g}, 40.4 \mathrm{mmol})$ was added. A solution of TBDMSCl $(4.5 \mathrm{~g}, 29.6 \mathrm{mmol})$ in dry $\mathrm{CH}_{2} \mathrm{Cl}_{2}(50 \mathrm{~mL})$ was added dropwise with an addition funnel and the resulting solution was left under vigorous stirring at r.t. for $18 \mathrm{~h}$. The suspension was filtered over a pad of Celite and the solvent was evaporated. The crude material obtained was purified over $\mathrm{SiO}_{2}$ with PE:EtOAc (95:5 to 4:1, v/v) yielding 10 as a yellowish oil $(8.11 \mathrm{~g}, 68 \%)$. $\mathrm{R}_{\mathrm{f}}(\mathrm{PE} / \mathrm{EtOAc}$ 4:1) 0.8. ${ }^{1} \mathrm{H} \mathrm{NMR}\left(300 \mathrm{MHz}, \mathrm{CDCl}_{3}\right): \delta_{\mathrm{H}}=4.18-4.08\left(\mathrm{~m}, 2 \mathrm{H}, \mathrm{C}(1) \mathrm{H}_{2}\right), 3.91-3.84(\mathrm{~m}, 1 \mathrm{H}, \mathrm{C}(2) \mathrm{H}), 3.68(\mathrm{dd}, J=10.2$, $5.6 \mathrm{~Hz}, 1 \mathrm{H}, \mathrm{C}(3) \mathrm{Hb}), 3.60(\mathrm{dd}, J=10.2,4.6 \mathrm{~Hz}, 1 \mathrm{H}, \mathrm{C}(3) \mathrm{Ha}), 2.34\left(\mathrm{t}, J=7.6 \mathrm{~Hz}, 2 \mathrm{H}, \mathrm{CH}_{2} \mathrm{COOR}\right), 1.65-1.68(\mathrm{~m}$, $\left.2 \mathrm{H}, \mathrm{CH}_{2} \mathrm{CH}_{2} \mathrm{COOR}\right), 1.25\left(\mathrm{~m}, 24 \mathrm{H}, 12 \times \mathrm{CH}_{2}\right), 0.93-0.90(\mathrm{~m}, 9 \mathrm{H}, \mathrm{t}-\mathrm{Bu}-\mathrm{Si}), 0.88-0.86\left(\mathrm{~m}, 3 \mathrm{H}, \mathrm{CH}_{3}\left(\mathrm{CH}_{2}\right)_{\mathrm{n}}\right), 0.08$ $\left(\mathrm{s}, 6 \mathrm{H}, \mathrm{CH}_{3} \mathrm{Si}\right) .{ }^{13} \mathrm{C} \mathrm{NMR}:{ }^{13} \mathrm{C}$ NMR: $\delta_{\mathrm{C}}=-5.4\left(2 \times \mathrm{CH}_{3}\right), 14.2\left(\mathrm{CH}_{3}\right), 18.4\left(\mathrm{Cq}{ }^{\mathrm{t}} \mathrm{Bu}\right), 22.8\left(\mathrm{CH}_{2}\right), 25.8\left(\mathrm{CH}_{2}\right), 25.9$ $\left(3 \times \mathrm{CH}_{3}\right), 29.3-29.8$ (series of $\left.\mathrm{CH}_{2}\right), 32.0\left(\mathrm{CH}_{2}\right), 34.3\left(\mathrm{CH}_{2}\right), 63.8(\mathrm{C} 1), 65.1(\mathrm{C} 2), 70.1(\mathrm{C} 3), 174.1(\mathrm{C}=\mathrm{O}) .[\alpha]_{\mathrm{D}}{ }^{25}=0.00$ (c $0.1, \mathrm{CHCl}_{3}$ ).

Compound 11. A quantity of $5 \mathrm{~g}$ of $\mathbf{1 0}(11.2 \mathrm{mmol})$ was dissolved in dry $\mathrm{CH}_{2} \mathrm{Cl}_{2}(50.0 \mathrm{~mL})$ and oleic acid $(3.5 \mathrm{~g}, 12.3 \mathrm{mmol})$ was added. The solution was cooled to $0{ }^{\circ} \mathrm{C}$ using an ice bath before DMAP $(0.4 \mathrm{~g}, 3.4 \mathrm{mmol})$ and $\mathrm{EDC} \cdot \mathrm{HCl}(2.8 \mathrm{~g}, 14.6 \mathrm{mmol})$ were added together. The resulting solution was left under vigorous stirring at r.t. for $18 \mathrm{~h}$. $75 \mathrm{~mL}$ of water were added to quench the reaction and the product was then extracted with $\mathrm{CH}_{2} \mathrm{Cl}_{2}(2 \times 50 \mathrm{~mL})$. The combined organic phases were dried over anhydrous $\mathrm{MgSO}_{4}$. The crude material obtained after evaporation of the solvent was purified over $\mathrm{SiO}_{2}$ with PE:EtOAc (99:1 to 9:1, v/v) giving 11 as a colorless oil (7.71 g, 97\%). $\mathrm{R}_{\mathrm{f}}(\mathrm{PE} / \mathrm{EtOAc} 16: 1)$ 0.7. ${ }^{1} \mathrm{H} \mathrm{NMR}\left(300 \mathrm{MHz}, \mathrm{CDCl}_{3}\right): \delta_{\mathrm{H}}=5.36-5.32(\mathrm{~m}, 2 \mathrm{H}$, $\mathrm{Z}-\mathrm{CH}=\mathrm{CH}), 5.09-5.05(\mathrm{~m}, 1 \mathrm{H}, \mathrm{CHOCOR}), 4.33$ (dd, $\left.J=11.8,3.7 \mathrm{~Hz}, 1 \mathrm{H}, \mathrm{SiOCH}_{2} \mathrm{CHCHaHbOCOR}\right), 4.16$ (dd, $\left.J=11.8,6.2 \mathrm{~Hz}, 1 \mathrm{H}, \mathrm{SiOCH}_{2} \mathrm{CHCHaHbOCOR}\right), 3.71\left(\mathrm{~d}, J=5.3 \mathrm{~Hz}, 2 \mathrm{H}, \mathrm{R}(\mathrm{O}) \mathrm{COCH}_{2} \mathrm{CHCHaHbOSi}_{2}, 2.33-2.27\right.$ (m, $\left.4 \mathrm{H}, 2 \times \mathrm{CH}_{2} \mathrm{COOR}\right), 2.04-1.97\left(\mathrm{~m}, 4 \mathrm{H}, \mathrm{CH}_{2}-\mathrm{CH}=\mathrm{CH}_{-} \mathrm{CH}_{2}\right), 1.64-1.58\left(\mathrm{~m}, 4 \mathrm{H}, 2 \times \mathrm{CH}_{2} \mathrm{CH}_{2} \mathrm{COOR}\right), 1.29(\mathrm{~m}, 44 \mathrm{H}$, $\left.22 \times \mathrm{CH}_{2}\right), 0.91-0.85\left(\mathrm{~m}, 15 \mathrm{H}, \mathrm{t}-\mathrm{Bu}-\mathrm{Si}, 2 \times \mathrm{CH}_{3}\right), 0.05\left(\mathrm{~s}, 6 \mathrm{H}, \mathrm{CH}_{3} \mathrm{Si}\right) .{ }^{13} \mathrm{C} \mathrm{NMR}: \delta_{\mathrm{C}}=-5.3\left(2 \times \mathrm{CH}_{3}\right), 14.3\left(\mathrm{CH}_{3}\right)$, $18.4(\mathrm{Cq} \mathrm{t} \mathrm{Bu}), 22.8\left(\mathrm{CH}_{2}\right), 25.1\left(2 \times \mathrm{CH}_{2}\right), 25.9\left(3 \times \mathrm{CH}_{3}\right), 27.3\left(2 \times \mathrm{CH}_{2}\right), 29.2-29.9\left(\right.$ series of $\left.\mathrm{CH}_{2}\right), 32.0\left(2 \times \mathrm{CH}_{2}\right)$, $34.3\left(\mathrm{CH}_{2}\right), 34.4\left(\mathrm{CH}_{2}\right), 61.6(\mathrm{C} 1), 62.6(\mathrm{C} 2), 71.8(\mathrm{C} 3), 129.9(\mathrm{Z}-\mathrm{CH}=\mathrm{CH}), 130.2(\mathrm{Z}-\mathrm{CH}=\mathrm{CH}), 173.3(\mathrm{C}=\mathrm{O}), 173.6$ $(\mathrm{C}=\mathrm{O}) \cdot[\alpha]_{\mathrm{D}}^{25}=0.00\left(\mathrm{c} 0.1, \mathrm{CHCl}_{3}\right)$.

Compound 7a. (Route C) A quantity of $7.71 \mathrm{~g}$ of $\mathbf{1 1}(10.9 \mathrm{mmol})$ was dissolved in a mixture of THF/MeCN $(50 / 50 \mathrm{~mL}, 1: 1 \mathrm{v} / \mathrm{v})$ and $\mathrm{Et}_{3} \mathrm{~N} \cdot 3 \mathrm{HF}(8.8 \mathrm{~g}, 54.3 \mathrm{mmol})$ was added slowly. The resulting solution was left under vigorous stirring at r.t. for $7 \mathrm{~h}$. $150 \mathrm{~mL}$ of saturated $\mathrm{NaHCO}_{3}$ were added drop wise to quench the reaction and the product was then extracted with $\mathrm{CH}_{2} \mathrm{Cl}_{2}(2 \times 100 \mathrm{~mL})$. The combined organic phases were washed with water $(100 \mathrm{~mL})$, dried over anhydrous $\mathrm{MgSO}_{4}$ and concentrated, giving $7 \mathbf{a}$ as a colorless oil $(6.36 \mathrm{~g}, 98 \%) .{ }^{1} \mathrm{H} \mathrm{NMR}$ $\left(300 \mathrm{MHz}^{\mathrm{CDCl}} \mathrm{CD}_{3}\right): \delta_{\mathrm{H}}=5.38-5.30(\mathrm{~m}, 2 \mathrm{H}, \mathrm{Z}-\mathrm{CH}=\mathrm{CH}), 5.11-5.05(\mathrm{~m}, 1 \mathrm{H}, \mathrm{CHOCOR}), 4.32(\mathrm{dd}, J=11.8,4.4 \mathrm{~Hz}$, $1 \mathrm{H}, \mathrm{C}(1) \mathrm{Hb}), 4.23(\mathrm{dd}, J=11.8,5.7 \mathrm{~Hz}, 1 \mathrm{H}, \mathrm{C}(1) \mathrm{Ha}), 3.76-3.70\left(\mathrm{~m}, 2 \mathrm{H}, \mathrm{C}(3) \mathrm{H}_{2}\right), 2.33(\mathrm{dd}, J=14.7,7.4 \mathrm{~Hz}, 4 \mathrm{H}$, $\left.2 \times \mathrm{CH}_{2} \mathrm{COOR}\right), 2.06-1.97\left(\mathrm{~m}, 4 \mathrm{H}, \mathrm{CH}_{2}-\mathrm{CH}=\mathrm{CH}-\mathrm{CH}_{2}\right), 1.68-1.56\left(\mathrm{~m}, 4 \mathrm{H}, 2 \times \mathrm{CH}_{2} \mathrm{CH}_{2} \mathrm{COOR}\right), 1.27(\mathrm{~m}, 44 \mathrm{H}$, $\left.22 \times \mathrm{CH}_{2}\right), 0.91-0.85\left(\mathrm{~m}, 6 \mathrm{H}, 2 \times \mathrm{CH}_{3}\right) .{ }^{13} \mathrm{C} \mathrm{NMR}: \delta_{\mathrm{C}}=14.3\left(\mathrm{CH}_{3}\right), 22.9\left(\mathrm{CH}_{2}\right), 25.1\left(\mathrm{CH}_{2}\right), 27.3\left(\mathrm{CH}_{2}\right), 27.4\left(\mathrm{CH}_{2}\right)$, $29.3\left(\mathrm{CH}_{2}\right), 29.5-29.9\left(\right.$ series of $\left.\mathrm{CH}_{2}\right), 30.0\left(\mathrm{CH}_{2}\right), 32.1\left(\mathrm{CH}_{2}\right), 34.3\left(\mathrm{CH}_{2}\right), 61.7(\mathrm{C} 3), 62.2(\mathrm{C} 1), 72.3(\mathrm{C} 2), 129.9$ $(\mathrm{Z}-\mathrm{CH}=\mathrm{CH}), 130.2(\mathrm{Z}-\mathrm{CH}=\mathrm{CH}), 174.0(\mathrm{C}=\mathrm{O}), 176.6(\mathrm{C}=\mathrm{O}) ;[\alpha]_{\mathrm{D}}{ }^{25}=0.00\left(\mathrm{c} 0.1, \mathrm{CHCl}_{3}\right)$.

Compound (S)-8. A quantity of $3.7 \mathrm{~g}(R)-(-)-2,2-D i m e t h y l-1,3-$ dioxolane-4-methanol $(S)-3 b(15.1 \mathrm{mmol})$ was dissolved in dry $\mathrm{CH}_{2} \mathrm{Cl}_{2}(40 \mathrm{~mL})$ and palmitic acid $(3.8 \mathrm{~g}, 15.1 \mathrm{mmol})$ was added. The solution was cooled to $0{ }^{\circ} \mathrm{C}$ using an ice bath, before DMAP $(0.5 \mathrm{~g}, 4.5 \mathrm{mmol})$ and $\mathrm{EDC} \cdot \mathrm{HCl}(3.8 \mathrm{~g}, 19.6 \mathrm{mmol})$ were added together. The resulting solution was left under vigorous stirring at r.t. for $18 \mathrm{~h} .75 \mathrm{~mL}$ of saturated $\mathrm{NaHCO}_{3}$ were added to quench the reaction and the product was then extracted with $\mathrm{CH}_{2} \mathrm{Cl}_{2}(2 \times 50 \mathrm{~mL})$. The combined organic phases were dried over anhydrous $\mathrm{MgSO}_{4}$. The crude material obtained after evaporation of the solvent was purified over $\mathrm{SiO}_{2}$ with PE:EtOAc $(99: 1$ to $85: 15, v / v)$ furnishing $(S)-8$ as a white powder $(5.55 \mathrm{~g}, 98 \%)$. $[\alpha]_{\mathrm{D}}{ }^{25}=0.80(\mathrm{c} 0.05$, $\mathrm{CHCl}_{3}$ )

Compound (S)-9. A quantity of $5.55 \mathrm{~g}$ of $(S)-8(14.9 \mathrm{mmol})$ was dissolved in a mixture of $\mathrm{AcOH} / \mathrm{H}_{2} \mathrm{O}$ $(60 / 15 \mathrm{~mL}, 4: 1 \mathrm{v} / \mathrm{v})$ and left under vigorous stirring at $55^{\circ} \mathrm{C}$ for $2 \mathrm{~h}$. The solution was cooled to r.t. and $75 \mathrm{~mL}$ of saturated $\mathrm{NaHCO}_{3}$ were added dropwise until the solution was neutralized. The product was then extracted with ethyl acetate $(2 \times 50 \mathrm{~mL})$. The combined organic phases were washed with brine $(50 \mathrm{~mL})$ and dried over 
anhydrous $\mathrm{MgSO}_{4}$. The solvent was evaporated furnishing (S)-9 as a white powder $(4.61 \mathrm{~g}, 94 \%)[\alpha]_{\mathrm{D}}^{25}=0.40$ (c $0.05, \mathrm{CHCl}_{3}$ )

Compound (R)-10. A quantity of $4.61 \mathrm{~g}$ of $(S)-9$ (13.94 mmol) was dissolved in dry $\mathrm{CH}_{2} \mathrm{Cl}_{2}(130.0 \mathrm{~mL})$ and imidazole (1.42 g, $20.9 \mathrm{mmol})$ was added. A solution of TBDMSCl $(2.3 \mathrm{~g}, 15.3 \mathrm{mmol})$ in dry $\mathrm{CH}_{2} \mathrm{Cl}_{2}(30 \mathrm{~mL})$ was added dropwise via an addition funnel and the resulting solution was left under vigorous stirring at r.t. for $18 \mathrm{~h}$. The suspension was filtered over a pad of Celite and solvent was evaporated. The crude material obtained was purified over $\mathrm{SiO}_{2}$ with PE:EtOAc (95:5 to 4:1, v/v) giving $(\boldsymbol{R})$-10 as a yellowish oil $(4.77 \mathrm{~g}, 76 \%) .[\alpha]_{\mathrm{D}}{ }^{25}=1.73$ (c $0.05, \mathrm{CHCl}_{3}$ )

Compound (R)-11. A quantity of $4.77 \mathrm{~g}$ of $(\boldsymbol{R})-\mathbf{1 0}(10.7 \mathrm{mmol})$ was dissolved in dry $\mathrm{CH}_{2} \mathrm{Cl}_{2}(50 \mathrm{~mL})$ and oleic acid ( $3.3 \mathrm{~g}, 11.7 \mathrm{mmol})$ was added. The solution was cooled to $0{ }^{\circ} \mathrm{C}$ using an ice bath before DMAP $(0.4 \mathrm{~g}$, $3.2 \mathrm{mmol})$ and $\mathrm{EDC} \cdot \mathrm{HCl}(2.6 \mathrm{~g}, 13.9 \mathrm{mmol})$ were added. The resulting solution was left under vigorous stirring at r.t. for $18 \mathrm{~h} 75 \mathrm{~mL}$ of water were added to quench the reaction and the product was then extracted with $\mathrm{CH}_{2} \mathrm{Cl}_{2}$ $(2 \times 50 \mathrm{~mL})$. The combined organic phases were dried over anhydrous $\mathrm{MgSO}_{4}$. The crude material obtained after evaporation of the solvent was purified over $\mathrm{SiO}_{2}$ with PE:EtOAc (99:1 to 9:1 v/v) giving (R)-11 as a colorless oil (7.35 g, 96\%). (R)-11: $[\alpha]_{\mathrm{D}}^{25}=2.31\left(\right.$ c $\left.0.05, \mathrm{CHCl}_{3}\right)$

Compound (S)-7a. A quantity of $7.35 \mathrm{~g}$ of $(\boldsymbol{R})-\mathbf{1 1}(10.3 \mathrm{mmol})$ was dissolved in a mixture of THF/MeCN $(50 / 50 \mathrm{~mL}, 1: 1 \mathrm{v} / \mathrm{v})$ and $\mathrm{Et}_{3} \mathrm{~N} \cdot 3 \mathrm{HF}(8.3 \mathrm{~g}, 51.2 \mathrm{mmol})$ was added slowly. The resulting solution was left under vigorous stirring at r.t. for $7 \mathrm{~h}$. $150 \mathrm{~mL}$ of saturated $\mathrm{NaHCO}_{3}$ were added dropwise to quench the reaction and the product was then extracted with $\mathrm{CH}_{2} \mathrm{Cl}_{2}(2 \times 100 \mathrm{~mL})$. The combined organic phases were washed with water $(100 \mathrm{~mL})$, dried over anhydrous $\mathrm{MgSO}_{4}$ and concentrated, giving $(S)-7 \mathrm{a}$ as a colorless oil $(6.08 \mathrm{~g}, 98 \%)$. $[\alpha]_{\mathrm{D}}^{25}=-0.60\left(\mathrm{c} 0.05, \mathrm{CHCl}_{3}\right)$

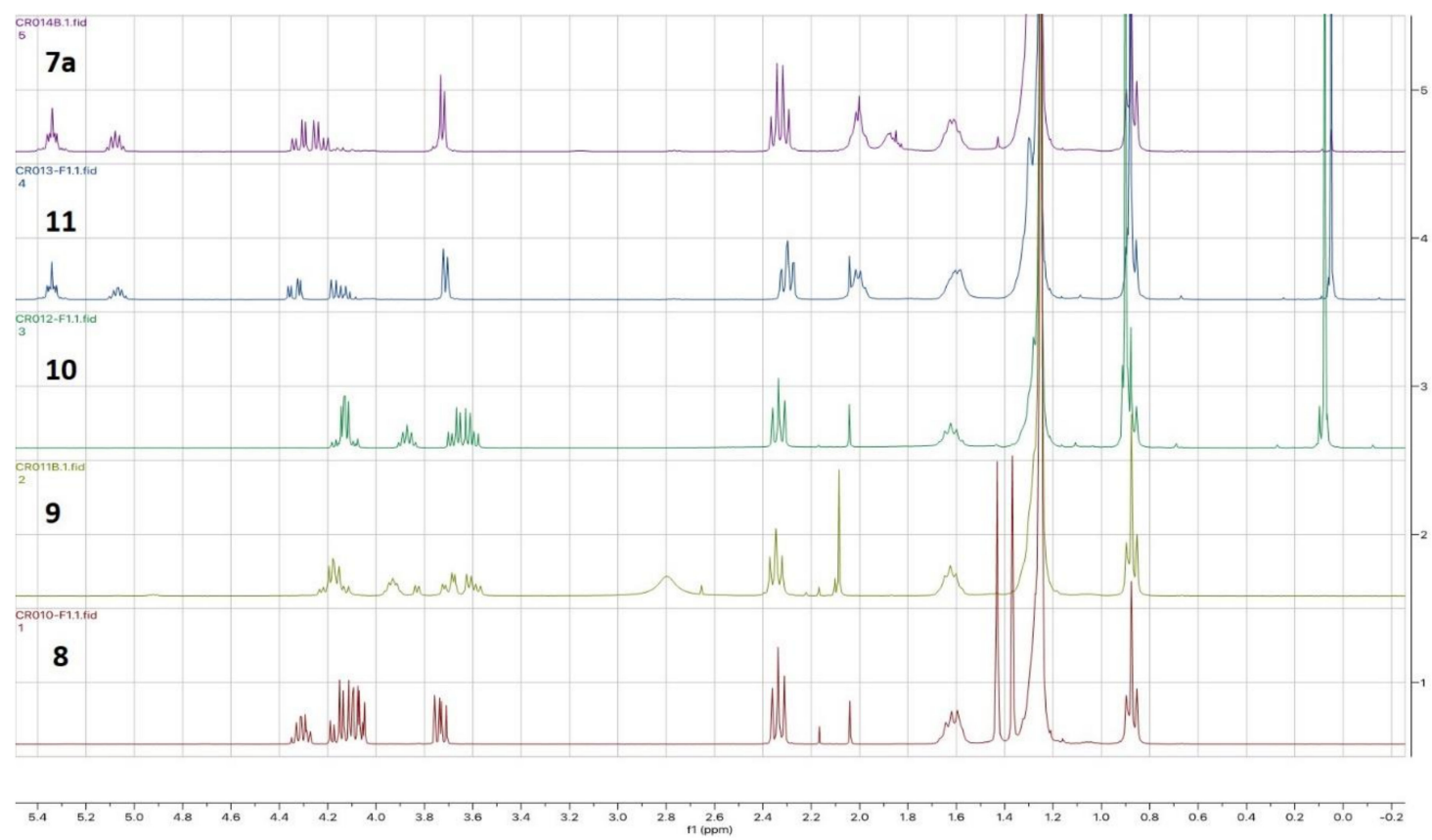

Figure A1. ${ }^{1} \mathrm{H}$ NMR spectra ( $300 \mathrm{MHz}, \mathrm{CDCl}_{3}$ ) of the racemic compounds 8 to 7 a obtained via Pathway C. The NMR spectra of compounds (S)-8 to $(S)-7 \mathbf{a}$ are identical.

Appendix A.3.4. Synthesis of Compounds 1a-1d and 2a-2c

Synthesis of 13a-13d and (R)-13a. General method. 7a-7d and (S)-7a were dissolved in dry toluene (6 mL) with dry $\mathrm{Et}_{3} \mathrm{~N}(0.025 \mathrm{~mL}, 0.178 \mathrm{mmol})$ and cooled $\left(0{ }^{\circ} \mathrm{C}\right)$. To this cold solution, a second solution prepared by dissolving 2-chloro-2-oxo-1,3,2-dioxaphospholane (12, 1.1 equiv.) in dry toluene $(4 \mathrm{~mL})$ were slowly added and the resulting mixture was stirred at r.t. The white precipitate obtained after $16 \mathrm{~h}$ was filtered off over a Celite pad $\left(2 \mathrm{~cm}\right.$ thick, $4 \mathrm{~cm} \varnothing$, filter porosity $\left.\mathrm{n}^{\circ} 4\right)$ and the filtrate was evaporated as quickly as possible while keeping the temperature of the water bath below $20{ }^{\circ} \mathrm{C} .{ }^{1} \mathrm{H}$ NMR and ${ }^{31} \mathrm{P} \mathrm{NMR}\left(\mathrm{CDCl}_{3}\right)$ were used to confirm the formation of 13a-13d that were used without further purifications for the next steps. Yields are reported in Table A2. (R)-13a was not used instead.

13a. ${ }^{1} \mathrm{H}$ NMR $\left(300 \mathrm{MHz}, \mathrm{CDCl}_{3}\right): \delta_{\mathrm{H}}=5.39-5.30(\mathrm{~m}, 2 \mathrm{H}, \mathrm{Z}-\mathrm{CH}=\mathrm{CH}), 5.28-5.21(\mathrm{~m}, 1 \mathrm{H}, \mathrm{C}(2) \mathrm{H}), 4.52-4.11$ $\left(\mathrm{m}, 4 \mathrm{H}, \mathrm{C}(1) \mathrm{H}_{2}\right.$ and $\left.\mathrm{O}-\mathrm{CH}_{2}-\mathrm{CH}_{2}-\mathrm{O}\right), 3.89-3.76\left(\mathrm{~m}, 2 \mathrm{H}, \mathrm{C}(1) \mathrm{H}_{2}\right), 2.34-2.30\left(\mathrm{~m}, 4 \mathrm{H}, 2 \times \mathrm{CH}_{2} \mathrm{COOR}\right), 2.01-1.94(\mathrm{~m}$, $\left.4 \mathrm{H}, 2 \times \mathrm{CH}_{2}-\mathrm{CH}=\mathrm{CH}-\mathrm{CH}_{2}\right), 1.60-1.54\left(\mathrm{~m}, 4 \mathrm{H}, 2 \times \mathrm{CH}_{2} \mathrm{CH}_{2} \mathrm{COOR}\right), 1.30,1.15\left(2 \times \mathrm{br}, 38 \mathrm{H}, 19 \times \mathrm{CH}_{2}\right), 0.96-0.76$ $\left(\mathrm{m}\right.$, superimposition of $2 \times \mathrm{t}$, apparent $\left.J=6.8 \mathrm{~Hz}, 6 \mathrm{H}, 2 \times \mathrm{CH}_{3}\right) .{ }^{31} \mathrm{P} \mathrm{NMR}\left(121.5 \mathrm{MHz}, \mathrm{CDCl}_{3}\right): \delta_{\mathrm{P}}=18.14$. 
Table A2. Data for the synthesis of 1a-1d and 2a-2c from 7a-7d.

\begin{tabular}{|c|c|c|c|c|c|c|c|}
\hline Entry & Step & Scale $^{1}$ & Yield & Entry & Step & Scale ${ }^{1}$ & Yield \\
\hline 1 & $7 a \rightarrow 13 a \rightarrow 1 a$ & $128 \mathrm{mg}$ & $70 \%$ & 7 & $7 a \rightarrow 13 a \rightarrow 2 a$ & $128 \mathrm{mg}$ & $43 \%$ \\
\hline 2 & $7 a \rightarrow 13 a \rightarrow 1 a$ & $1.0 \mathrm{~g}$ & $65 \%$ & 8 & $7 b \rightarrow 13 b \rightarrow 2 b$ & $56 \mathrm{mg}$ & $35 \%$ \\
\hline 3 & $7 b \rightarrow 13 b \rightarrow 1 b$ & $56 \mathrm{mg}$ & $51 \%$ & 9 & $7 c \rightarrow 13 c \rightarrow 2 c$ & $82 \mathrm{mg}$ & $41 \%$ \\
\hline 4 & $7 c \rightarrow 13 c \rightarrow 1 c$ & $82 \mathrm{mg}$ & $27 \%$ & & & & \\
\hline 5 & $7 d \rightarrow 13 d \rightarrow 1 d$ & $100 \mathrm{mg}$ & $45 \%$ & & & & \\
\hline 6 & $(S)-7 \mathrm{a} \rightarrow(R)-13 \mathrm{a}$ & $50 \mathrm{mg}$ & quant. & & & & \\
\hline
\end{tabular}

${ }^{1}$ with respect to the amount $7 \mathbf{a}-\mathbf{d}(S)-7 \mathbf{a}$ and $7 \mathbf{a}-\mathbf{c}$ used.

13b. (The mixture contained unreacted $\mathbf{5 b}$ : ratio 5b/12a 1:4 by ${ }^{1} \mathrm{H}$ NMR integration). ${ }^{1} \mathrm{H}$ NMR (300 MHz, $\left.\mathrm{CDCl}_{3}\right): \delta_{\mathrm{H}}=5.40-5.28(\mathrm{~m}, 4 \mathrm{H}, 2 \times \mathrm{Z}-\mathrm{CH}=\mathrm{CH}, 6 \mathbf{b}+7 \mathbf{b}), 5.27-5.20(\mathrm{~m}, 1 \mathrm{H}, \mathrm{C}(2) \mathrm{H}), 5.16-4.80(\mathrm{~m}, 2 \mathrm{H}$, $\left.1 \times \mathrm{CH}_{2} \mathrm{NHR}\right), 4.40-4.05\left(\mathrm{~m}, 8 \mathrm{H}, \mathrm{C}(1) \mathrm{H}_{2}\right.$ and $\left.\mathrm{C}(1) \mathrm{H}_{2} \mathbf{5 b}+\mathbf{1 2 b}\right), 3.78-3.87\left(\mathrm{~m}, 2 \mathrm{H}, \mathrm{NHCH}_{2} \mathrm{CH}_{2} \mathrm{OR}\right), 2.62-2.69$ (m, $\left.2 \mathrm{H}, 1 \times \mathrm{CH}_{2}-\mathrm{CH}=\mathrm{CH}-\mathrm{CH}_{2}\right), 2.40-2.25\left(\mathrm{~m}, 4 \mathrm{H}, \mathrm{CH}_{2} \mathrm{CH}_{2} \mathrm{COOR}, 5 \mathbf{b}+\mathbf{1 2 b}\right), 2.11-1.96\left(\mathrm{~m}, 6 \mathrm{H}, 3 \times \mathrm{CH}_{2}-\mathrm{CH}=\mathrm{CH}-\mathrm{CH}_{2}\right.$, $\mathbf{5 b}+\mathbf{1 2 b}), 1.60-1.55\left(\mathrm{~m}, 4 \mathrm{H}, 2 \times \mathrm{CH}_{2} \mathrm{CH}_{2} \mathrm{COOR}, \mathbf{5 b}+\mathbf{1 2 b}\right), 1.39,1.26\left(2 \times \mathrm{br}, 40 \mathrm{H}, 20 \times \mathrm{CH}_{2}, \mathbf{5 b}+\mathbf{1 2 b}\right), 0.96-0.76(\mathrm{~m}$, $\left.6 \mathrm{H}, 2 \times \mathrm{CH}_{3}, 6 \mathbf{b}+7 \mathbf{b}\right) .{ }^{31} \mathrm{P} \mathrm{NMR}\left(121.5 \mathrm{MHz}, \mathrm{CDCl}_{3}\right): \delta_{\mathrm{P}}=17.63$.

13c. ${ }^{1} \mathrm{H}$ NMR $\left(300 \mathrm{MHz}, \mathrm{CDCl}_{3}\right.$, selected signals): $\delta_{\mathrm{H}}=5.30-5.16(\mathrm{~m}, 1 \mathrm{H}, \mathrm{C}(2) \mathrm{H}), 3.81-3.68(\mathrm{~m}, 3 \mathrm{H}), 2.37-2.28$ (m, $\left.4 \mathrm{H}, \mathrm{CH}_{2} \mathrm{CH}_{2} \mathrm{COOR}\right), 1.70-1.53$ (m, $\left.4 \mathrm{H}, 2 \times \mathrm{CH}_{2} \mathrm{CH}_{2} \mathrm{COOR}\right), 1.39,1.25$ (2 x br, $\left.44 \mathrm{H}, 22 \times \mathrm{CH}_{2}\right), 0.87(\mathrm{t}$, $\left.J=6.9 \mathrm{~Hz}, 2 \times \mathrm{CH}_{3}\right) ;{ }^{31} \mathrm{P} \mathrm{NMR}\left(121.5 \mathrm{MHz}, \mathrm{CDCl}_{3}\right): \delta_{\mathrm{P}}=17.38$.

13d. ${ }^{1} \mathrm{H}$ NMR $\left(300 \mathrm{MHz}, \mathrm{CDCl}_{3}\right.$, selected signals): $\delta_{\mathrm{H}}=5.20-5.18(\mathrm{~m}, 1 \mathrm{H}, \mathrm{C}(2) \mathrm{H}), 2.40-2.23(\mathrm{~m}, 4 \mathrm{H}$, $\left.\mathrm{CH}_{2} \mathrm{CH}_{2} \mathrm{COOR}\right), 1.77-1.50\left(\mathrm{~m}, 4 \mathrm{H}, 2 \times \mathrm{CH}_{2} \mathrm{CH}_{2} \mathrm{COOR}\right), 1.22\left(\mathrm{br}, 40 \mathrm{H}, 20 \times \mathrm{CH}_{2}\right), 0.87\left(\mathrm{t}, \mathrm{J}=6.9 \mathrm{~Hz}, 2 \times \mathrm{CH}_{3}\right){ }^{31} \mathrm{P}$ NMR (121.5 MHz, $\left.\mathrm{CDCl}_{3}\right): \delta_{\mathrm{P}}=17.68$.

(R)-13a. ${ }^{1} \mathrm{H}$ NMR $\left(300 \mathrm{MHz}, \mathrm{CDCl}_{3}\right)$ : $\delta_{\mathrm{H}}=5.39-5.30(\mathrm{~m}, 2 \mathrm{H}, \mathrm{Z}-\mathrm{CH}=\mathrm{CH}), 5.28-5.21(\mathrm{~m}, 1 \mathrm{H}, \mathrm{C}(2) \mathrm{H}), 4.52-4.11$ $\left(\mathrm{m}, 4 \mathrm{H}, \mathrm{C}(1) \mathrm{H}_{2}\right.$ and $\left.\mathrm{O}-\mathrm{CH}_{2}-\mathrm{CH}_{2}-\mathrm{O}\right), 3.89-3.76(\mathrm{~m}, 2 \mathrm{H}, \mathrm{C}(1) \mathrm{H} 2), 2.34-2.30\left(\mathrm{~m}, 4 \mathrm{H}, 2 \times \mathrm{CH}_{2} \mathrm{COOR}\right), 2.01-1.94(\mathrm{~m}$, $\left.4 \mathrm{H}, 2 \times \mathrm{CH}_{2}-\mathrm{CH}=\mathrm{CH}-\mathrm{CH}_{2}\right), 1.60-1.54\left(\mathrm{~m}, 4 \mathrm{H}, 2 \times \mathrm{CH}_{2} \mathrm{CH}_{2} \mathrm{COOR}\right), 1.30,1.15$ (2 x br, $\left.38 \mathrm{H}, 19 \times \mathrm{CH}_{2}\right), 0.96-0.76$ $\left(\mathrm{m}\right.$, superimposition of $2 \times \mathrm{t}$, apparent $\left.J=6.8 \mathrm{~Hz}, 6 \mathrm{H}, 2 \times \mathrm{CH}_{3}\right) \cdot{ }^{31} \mathrm{P} \mathrm{NMR}\left(121.5 \mathrm{MHz}, \mathrm{CDCl}_{3}\right): \delta_{\mathrm{P}}=18.14$.

Synthesis of racemic phosphocholines 1a-1d. General method. Cyclic phosphotriesters 13a-13d were dissolved in dry $\mathrm{MeCN}(10 \mathrm{~mL})$ and placed in a pressure tube (Sigma Aldrich) equipped with a rubber septum and connected to an Ar reservoir and the tube was placed in an ice bath $\left(0^{\circ} \mathrm{C}\right)$. Dry trimethylamine $(0.5 \mathrm{~mL}, 0.49 \mathrm{mmol})$ was added, the tube sealed and the resulting white solution was kept stirring at $65^{\circ} \mathrm{C}$ for $24 \mathrm{~h}$. The solution was cooled to r.t. and the resulting mixture was purified by chromatography over freshly activated $\mathrm{SiO}_{2}$ with $\mathrm{CHCl}_{3} / \mathrm{MeOH} / \mathrm{H}_{2} \mathrm{O}$ 65:25:0.4 $v / v / v$ furnishing products 1a-1d as white waxes. Only the 1a reaction was scaled up to $1 \mathrm{~g}$ of $7 \mathrm{a}$. Data were reported in Table A2.

1a. Obtained $36 \mathrm{mg}(70 \%)$, the scale-up reaction $(1 \mathrm{gr})$ yielded $508 \mathrm{mg}(65 \%) ; \mathrm{R}_{\mathrm{f}}\left(65: 25: 04, \mathrm{CHCl}_{3}: \mathrm{MeOH}\right.$ : $\left.\mathrm{H}_{2} \mathrm{O}, v / v / v\right)$ 0.65. ${ }^{1} \mathrm{H}$ NMR $\left(300 \mathrm{MHz}, \mathrm{CDCl}_{3}\right): \delta_{\mathrm{H}}=5.41-5.27(\mathrm{~m}, 2 \mathrm{H}, \mathrm{Z}-\mathrm{CH}=\mathrm{CH}), 5.23(\mathrm{br}, 1 \mathrm{H}, \mathrm{C}(2) \mathrm{H}), 4.43-4.94(\mathrm{~m}$, $\left.4 \mathrm{H}, \mathrm{O}-\mathrm{CH}_{2}-\mathrm{CH}_{2}-\mathrm{NMe}_{3}\right), 3.73$ (br, $\left.2 \mathrm{H}, \mathrm{C}(1) \mathrm{H}_{2}\right), 3.99$ (br, $\left.2 \mathrm{H}, \mathrm{C}(3) \mathrm{H}_{2}\right), 2.39-2.22\left(\mathrm{~m}, 4 \mathrm{H}, 2 \times \mathrm{CH}_{2} \mathrm{COOR}\right), 2.01-1.94$ $\left(\mathrm{m}, 4 \mathrm{H}, 2 \times \mathrm{CH}_{2}-\mathrm{CH}=\mathrm{CH}-\mathrm{CH}_{2}\right), 1.66-1.50\left(\mathrm{~m}, 4 \mathrm{H}, 2 \times \mathrm{CH}_{2} \mathrm{CH}_{2} \mathrm{COOR}\right), 1.30,1.15$ (2 x br, $53 \mathrm{H}, 19 \times \mathrm{CH}_{2}$ and $\left.\mathrm{N}\left(\mathrm{CH}_{3}\right)_{3}\right), 0.95-0.79(\mathrm{~m}$, superimposition of $2 \times \mathrm{t}$, apparent $\left.J=6.8 \mathrm{~Hz}), 6 \mathrm{H}, 2 \times \mathrm{CH}_{3}\right) .{ }^{13} \mathrm{C} \mathrm{NMR}\left(75 \mathrm{MHz} \mathrm{CDCl}_{3}\right)$ : $\delta \mathrm{C}=$ (selected signals) $14.3\left(\mathrm{CH}_{3}\right), 22.9\left(\mathrm{CH}_{2}\right), 25.0\left(\mathrm{CH}_{2}\right), 25.1\left(\mathrm{CH}_{2}\right), 27.4\left(\mathrm{CH}_{2}\right), 29.4\left(\mathrm{CH}_{2}\right), 29.5\left(\mathrm{CH}_{2}\right), 29.6\left(\mathrm{CH}_{2}\right)$, 29.9-32.0 (series of $\left.\mathrm{CH}_{2}\right), 32.1\left(\mathrm{CH}_{2}\right), 34.3\left(\mathrm{CH}_{2}\right), 61.7(\mathrm{C} 3), 62.9(\mathrm{C} 1), 70.6(\mathrm{C} 2, \mathrm{HSQC}), 129.6(\mathrm{Z}-\mathrm{CH}=\mathrm{CH}), 130.2$ $(\mathrm{Z}-\mathrm{CH}=\mathrm{CH}), 173.6(\mathrm{C}=\mathrm{O}), 173.8(\mathrm{C}=\mathrm{O}) ;{ }^{31} \mathrm{P}$ NMR $\left(121.5 \mathrm{MHz}, \mathrm{CDCl}_{3}\right): \delta_{\mathrm{P}}=-1.65 ;[\alpha]_{\mathrm{D}}{ }^{25}=0.00\left(\mathrm{c} 0.1, \mathrm{CHCl}_{3}\right)$; $[\alpha]_{\mathrm{D}}{ }^{25}=0.00\left(\right.$ c $\left.0.1, \mathrm{CHCl}_{3}\right)$; HRMS m/z: $[\mathrm{M}]^{+}$calcd. for $\mathrm{C}_{42} \mathrm{H}_{82} \mathrm{NNaO}_{8} \mathrm{P}: 782.5675$, found $\mathrm{C}_{42} \mathrm{H}_{82} \mathrm{NNaO}_{8} \mathrm{P}$ : 782.5670 .

1b. Obtained $35.4 \mathrm{mg}(51 \%) ; \mathrm{R}_{\mathrm{f}}\left(\mathrm{CHCl}_{3}\right.$ : $\left.\mathrm{MeOH}: \mathrm{H}_{2} \mathrm{O}, 65: 25: 0.4 \mathrm{v} / \mathrm{v} / \mathrm{v}\right)$ 0.64. ${ }^{1} \mathrm{H} \mathrm{NMR}\left(400 \mathrm{MHz}, \mathrm{CDCl}_{3}\right)$ : $\delta_{\mathrm{H}}=5.39-5.29(\mathrm{~m}, 2 \mathrm{H}, \mathrm{Z}-\mathrm{CH}=\mathrm{CH}), 5.23(\mathrm{br}, 1 \mathrm{H}, \mathrm{C}(2) \mathrm{H}), 4.51(\mathrm{br}, 2 \mathrm{H}, \mathrm{OH}), 4.16-4.11\left(\mathrm{~m}, 2 \mathrm{H}, \mathrm{C}(1) \mathrm{H}_{2}\right) ; 4.11-3.96(\mathrm{~m}$, $6 \mathrm{H}, \mathrm{O}-\mathrm{CH}_{2}-\mathrm{CH}_{2}-\mathrm{NMe}_{3}$ and $\left.\mathrm{C}(1) \mathrm{H}_{2}\right), 2.37-2.26\left(\mathrm{~m}, 4 \mathrm{H}, 2 \times \mathrm{CH}_{2} \mathrm{COOR}\right), 2.06-1.93\left(\mathrm{~m}, 4 \mathrm{H}, 2 \times \mathrm{CH}_{2}-\mathrm{CH}=\mathrm{CH}-\mathrm{CH}_{2}\right)$, 1.63-1.49 (m, $\left.4 \mathrm{H}, 2 \times \mathrm{CH}_{2} \mathrm{CH}_{2} \mathrm{COOR}\right), 1.38,1.15\left(2 \times \mathrm{br}, 53 \mathrm{H}, 19 \times \mathrm{CH}_{2}\right.$ and $\left.\mathrm{N}\left(\mathrm{CH}_{3}\right)_{3}\right), 0.95-0.79$ (m, superimposition of $2 \times \mathrm{t}$, apparent $\left.J=6.8 \mathrm{~Hz}, 6 \mathrm{H}, 2 \times \mathrm{CH}_{3}\right) .{ }^{13} \mathrm{C} \mathrm{NMR}\left(100 \mathrm{MHz}, \mathrm{CDCl}_{3}\right): \delta_{\mathrm{C}}=($ selected signals $) 14.3\left(\mathrm{CH}_{3}\right)$, $22.9\left(\mathrm{CH}_{2}\right), 24.9\left(\mathrm{CH}_{2} \mathrm{CH}_{2} \mathrm{COOR}\right), 27.3$ and $27.4\left(\mathrm{CH}_{2}-\mathrm{CH}=\mathrm{CH}-\mathrm{CH}_{2}, \mathrm{HSQC}\right), 29.4-29.5$ (series of $\left.\mathrm{CH}_{2}\right), 29.8\left(\mathrm{CH}_{2}\right)$, $29.9\left(\mathrm{CH}_{2}\right), 30.0\left(\mathrm{CH}_{2}\right), 32.1\left(\mathrm{CH}_{2}\right), 34.1\left(\mathrm{CH}_{2} \mathrm{COOR}\right), 62.4(\mathrm{C} 3, \mathrm{HSQC}), 64.6(\mathrm{C} 1, \mathrm{HSQC}), 69.8$ (C2, HSQC), 129.9 $(\mathrm{Z}-\mathrm{CH}=\mathrm{CH}), 130.2(\mathrm{Z}-\mathrm{CH}=\mathrm{CH}), 173.4(\mathrm{C}=\mathrm{O}), 173.7(\mathrm{C}=\mathrm{O}) ;{ }^{31} \mathrm{P} \mathrm{NMR}\left(121.5 \mathrm{MHz}, \mathrm{CDCl}_{3}\right): \delta_{\mathrm{P}}=-2.33 ;[\alpha]_{\mathrm{D}}{ }^{25}=0.00$ (c $0.1, \mathrm{CHCl}_{3}$ ); HRMS m/z: [M] $]^{+}$calcd. for $\mathrm{C}_{44} \mathrm{H}_{85} \mathrm{NO}_{8} \mathrm{P}: 786.6013$, found $\mathrm{C}_{44} \mathrm{H}_{85} \mathrm{NO}_{8} \mathrm{P}: 786.6007$.

1c. Obtained $33.0 \mathrm{mg}(45 \%) . \mathrm{R}_{\mathrm{f}}\left(\mathrm{CHCl}_{3}: \mathrm{MeOH}: \mathrm{H}_{2} \mathrm{O}, 65: 25: 0.4 \mathrm{v} / \mathrm{v} / \mathrm{v}\right) 0.72 .{ }^{1} \mathrm{H} \mathrm{NMR}\left(400 \mathrm{MHz}, \mathrm{CDCl}_{3}\right)$ : $\delta_{\mathrm{H}}=5.17-5.22(\mathrm{~m}, 1 \mathrm{H}, \mathrm{C}(2) \mathrm{H}), 4.34-4.26\left(\mathrm{~m}, 2 \mathrm{H}, \mathrm{O}-\mathrm{CH}_{2}-\mathrm{CH}_{2}-\mathrm{NH}_{2}\right), 4.12\left(\mathrm{dd}, J=12.0,2.8 \mathrm{~Hz}, 2 \mathrm{H}, \mathrm{C}(2) \mathrm{H}_{2}\right)$, 3.99-3.86 (m, $\left.2 \mathrm{H}, \mathrm{C}(3) \mathrm{H}_{2}\right), 3.81-3.75\left(\mathrm{~m}, 2 \mathrm{H}, \mathrm{CH}_{2}-\mathrm{NH}_{2}\right), 3.45\left(\mathrm{~s}, 9 \mathrm{H}, \mathrm{N}\left(\mathrm{CH}_{3}\right)_{3}\right), 2.28(\mathrm{dd}, 4 \mathrm{H}, J=15.4,8 \mathrm{~Hz}, 4 \mathrm{H}$, $\left.2 \times \mathrm{CH}_{2} \mathrm{COOR}\right), 1.62-1.51\left(\mathrm{~m}, 4 \mathrm{H}, 2 \times \mathrm{CH}_{2} \mathrm{CH}_{2} \mathrm{COOR}\right), 1.30,1.25\left(2 \times \mathrm{br}, 48 \mathrm{H}, 24 \times \mathrm{CH}_{2}\right), 0.87(\mathrm{t}, 6 \mathrm{H}, J=6.9 \mathrm{~Hz})$, $\left.6 \mathrm{H}, 2 \times \mathrm{CH}_{3}\right) .{ }^{13} \mathrm{C} \mathrm{NMR}\left(100 \mathrm{MHz}, \mathrm{CDCl}_{3}\right): \delta_{\mathrm{C}}=$ (selected signals) $14.3\left(\mathrm{CH}_{3}\right), 25.1\left(\mathrm{CH}_{2}\right), 25.2\left(\mathrm{CH}_{2}\right), 29.2\left(\mathrm{CH}_{2}\right)$, $29.3\left(\mathrm{CH}_{2}\right), 29.4\left(\mathrm{CH}_{2}\right), 29.5\left(\mathrm{CH}_{2}\right), 29.6\left(\mathrm{CH}_{2}\right), 29.8\left(\mathrm{CH}_{2}\right), 29.9\left(\mathrm{CH}_{2}\right), 30.0\left(\mathrm{CH}_{2}\right), 32.0\left(\mathrm{CH}_{2}\right), 34.4\left(\mathrm{CH}_{2}\right), 34.5$ $\left(\mathrm{CH}_{2}\right), 63.2(\mathrm{C} 3), 62.9(\mathrm{C} 1), 70.6(\mathrm{C} 2, \mathrm{HSQC}), 173.4(\mathrm{C}=\mathrm{O}), 173.8(\mathrm{C}=\mathrm{O}) ;{ }^{31} \mathrm{P} \mathrm{NMR}(121.5 \mathrm{MHz}, \mathrm{CDCl}): \delta_{\mathrm{P}}=-2.45$; $[\alpha]_{\mathrm{D}}{ }^{25}=0.00\left(\mathrm{c} 0.1, \mathrm{CHCl}_{3}\right.$ ); HRMS $\mathrm{m} / z$ : $[\mathrm{M}]^{+}$calcd. for $\mathrm{C}_{40} \mathrm{H}_{80} \mathrm{NNaO}_{8} \mathrm{P}: 756.5519$, found $\mathrm{C}_{40} \mathrm{H}_{80} \mathrm{NNaO}_{8} \mathrm{P}$ : 756.5428 .

1d. Obtained $28.7 \mathrm{mg}(26 \%) ; \mathrm{R}_{\mathrm{f}}\left(\mathrm{CHCl}_{3}: \mathrm{MeOH}: \mathrm{H}_{2} \mathrm{O}, 65: 25: 04 \mathrm{v} / \mathrm{v} / \mathrm{)}\right)$ 0.70. ${ }^{1} \mathrm{H} \mathrm{NMR}\left(300 \mathrm{MHz}, \mathrm{CDCl}_{3}\right)$ : $\delta_{\mathrm{H}}=5.24(\mathrm{br}, 1 \mathrm{H}, \mathrm{C}(2) \mathrm{H}), 4.39-4.20\left(\mathrm{~m}, 4 \mathrm{H}, \mathrm{O}-\mathrm{CH}_{2}-\mathrm{CH}_{2}-\mathrm{NMe}_{3}\right), 4.19-4.09(\mathrm{~m}, 1 \mathrm{H}, \mathrm{C}(3) \mathrm{Hb}), 4.04\left(\mathrm{br}, 1 \mathrm{H}, \mathrm{C}(1) \mathrm{H}_{2}\right)$, 
3.76 (br, $2 \mathrm{H}, \mathrm{C}(3) \mathrm{Ha}), 2.85$ (br, $9 \mathrm{H}, \mathrm{N}\left(\mathrm{CH}_{3}\right), 2.37-2.30$ (m, 4H, $\left.2 \times \mathrm{CH}_{2} \mathrm{COOR}\right), 1.66-1.51$ (m, 4H, $2 \times \mathrm{CH}_{2} \mathrm{CH}_{2} \mathrm{COOR}_{\text {, }}$ $1.23\left(\mathrm{br}, 32 \mathrm{H}, 16 \times \mathrm{CH}_{2}\right), 0.87\left(\mathrm{t}, 6 \mathrm{H}, \mathrm{J}=6.8 \mathrm{~Hz}, 2 \times \mathrm{CH}_{3}\right) .{ }^{13} \mathrm{C} \mathrm{NMR}\left(75 \mathrm{MHz}, \mathrm{CDCl}_{3}\right): \delta_{\mathrm{C}}=($ selected signals) 14.3 $\left(\mathrm{CH}_{3}\right), 22.9\left(\mathrm{CH}_{2}\right), 23.7\left(\mathrm{CH}_{2}\right), 24.7\left(\mathrm{CH}_{2}\right), 25.1\left(\mathrm{CH}_{2} \mathrm{CH}_{2} \mathrm{COOR}\right), 27.4\left(\mathrm{CH}_{2}\right), 29.5\left(\mathrm{CH}_{2}\right), 29.8\left(\mathrm{CH}_{2}\right), 29.6\left(\mathrm{CH}_{2}\right)$, $32.1\left(\mathrm{CH}_{2}\right), 34.4\left(\mathrm{CH}_{2} \mathrm{COOR}\right), 62.5(\mathrm{C} 3, \mathrm{HSQC}), 64.4(\mathrm{C} 1, \mathrm{HSQC}), 70.3(\mathrm{C} 2, \mathrm{HSQC}), 173.2(\mathrm{C}=\mathrm{O}), 173.6(\mathrm{C}=\mathrm{O}) ;{ }^{31} \mathrm{P}$ $\operatorname{NMR}\left(121.5 \mathrm{MHz}, \mathrm{CDCl}_{3}\right): \delta_{\mathrm{P}}=-2.05 ;[\alpha]_{\mathrm{D}}^{25}=0.00\left(\mathrm{c} 0.1, \mathrm{CHCl}_{3}\right)$; HRMS (m/z): $[\mathrm{M}]+$ calcd. for $\mathrm{C}_{36} \mathrm{H}_{73} \mathrm{NO}_{8} \mathrm{P}$ : 678.5074, found $\mathrm{C}_{36} \mathrm{H}_{73} \mathrm{NO}_{8} \mathrm{P}: 678.5068$.

Synthesis of racemic phosphoethanolamines 2a-2c. General method. 13a-14c were dissolved in $\mathrm{dry}_{\mathrm{CH}} \mathrm{CN}$ $(10 \mathrm{~mL})$ in a pressure tube (Sigma Aldrich) equipped with a rubber septum and connected to an Ar reservoir and the tube was placed in an ice bath $\left(0^{\circ} \mathrm{C}\right)$. Dry $\mathrm{NH}_{3}$ (3.5 bar, excess) was bubbled into the tube until the solution became white $(2 \mathrm{~min})$. The tube was sealed and the resulting white solution was kept under stirring at $65^{\circ} \mathrm{C}$ for $24 \mathrm{~h}$. The solution was cooled to r.t. and the resulting mixture was purified by chromatography over freshly activated $\mathrm{SiO}_{2}$ with $\mathrm{CHCl}_{3}$ : MeOH: $\mathrm{H}_{2} \mathrm{O}(65: 25: 0.4 \mathrm{v} / \mathrm{v} / \mathrm{v})$ yielding $\mathbf{2 a}-\mathbf{2} \mathbf{c}$ as white waxes. Reactions carried out by using a $1.0 \mathrm{M}$ solution of $\mathrm{NH}_{3}$ in dry acetonitrile gave similar results. Data were reported in Table A2

2a. Obtained $66.4 \mathrm{mg}(43 \%) ; \mathrm{R}_{\mathrm{f}}\left(\mathrm{CHCl}_{3}\right.$ : MeOH: $\left.\mathrm{H}_{2} \mathrm{O}, 65: 25: 04 \mathrm{v} / \mathrm{v} / \mathrm{v}\right)$ 0.67; ${ }^{1} \mathrm{H} \mathrm{NMR}\left(400 \mathrm{MHz}, \mathrm{CDCl}_{3}\right)$ : $\delta_{\mathrm{H}}=5.37-5.28(\mathrm{~m}, 2 \mathrm{H}, \mathrm{Z}-\mathrm{CH}=\mathrm{CH}), 5.26-5.13(\mathrm{~m}, 1 \mathrm{H}, \mathrm{C}(2) \mathrm{H}), 4.41-4.33(\mathrm{~m}, 1 \mathrm{H}, \mathrm{C}(1) \mathrm{Hb}), 4.21-4.04(\mathrm{~m}, 3 \mathrm{H}$, $\mathrm{C}(1) \mathrm{Ha}$ and $\left.\mathrm{O}-\mathrm{CH}_{2}-\mathrm{CH}_{2}-\mathrm{NH}_{3}{ }^{+}\right), 3.97-3.92\left(\mathrm{~m}, 2 \mathrm{H}, \mathrm{O}-\mathrm{CH}_{2}-\mathrm{CH}_{2}-\mathrm{NH}_{3}{ }^{+}\right), 3.26-3.10\left(\mathrm{~m}, 2 \mathrm{H}, \mathrm{C}(3) \mathrm{H}_{2}\right), 2.36-2.22$ (m, $\left.4 \mathrm{H}, 2 \times \mathrm{CH}_{2} \mathrm{COOR}\right), 2.07-1.95\left(\mathrm{~m}, 4 \mathrm{H}, 2 \times \mathrm{CH}_{2}-\mathrm{CH}=\mathrm{CH}-\mathrm{CH}_{2}\right), 1.66-1.51\left(\mathrm{~m}, 4 \mathrm{H}, 2 \times \mathrm{CH}_{2} \mathrm{CH}_{2} \mathrm{COOR}\right), 1.25$ $\left(\mathrm{br}, 44 \mathrm{H}, 22 \times \mathrm{CH}_{2}\right), 0.85\left(\mathrm{t}, J=6.8 \mathrm{~Hz}, 6 \mathrm{H}, 2 \times \mathrm{CH}_{3}\right) ;{ }^{13} \mathrm{C} \mathrm{NMR}\left(100 \mathrm{MHz}, \mathrm{CDCl}_{3}\right): \delta_{\mathrm{C}}=($ selected signals $) 14.3$ $\left(\mathrm{CH}_{3}\right), 22.9\left(\mathrm{CH}_{2}\right), 27.4$ (series of $\left.\mathrm{CH}_{2}\right), 29.4\left(\mathrm{CH}_{2}\right), 29.5\left(\mathrm{CH}_{2}\right), 29.6\left(\mathrm{CH}_{2}-\mathrm{CH}=\mathrm{CH}-\mathrm{CH}_{2}\right)$, 29.9-30.0 (series of $\left.\mathrm{CH}_{2}\right), 62.7(\mathrm{C} 3), 64.2(\mathrm{C} 1), 70.4(\mathrm{C} 2), 129.9(\mathrm{Z}-\mathrm{CH}=\mathrm{CH}), 130.2(\mathrm{Z}-\mathrm{CH}=\mathrm{CH}), 173.2(\mathrm{C}=\mathrm{O}), 173.6(\mathrm{C}=\mathrm{O}) ;{ }^{31} \mathrm{P} \mathrm{NMR}$ $\left(121.5 \mathrm{MHz}, \mathrm{CDCl}_{3}\right): \delta_{\mathrm{P}}=-0.17 ;[\alpha]_{\mathrm{D}}{ }^{25}=0.00\left(\mathrm{c} 0.1, \mathrm{CHCl}_{3}\right)$; HRMS m/z: $[\mathrm{M}]^{+}$calcd. for $\mathrm{C}_{39} \mathrm{H}_{77} \mathrm{NO}_{8} \mathrm{P}: 718.5387$, found $\mathrm{C}_{39} \mathrm{H}_{77} \mathrm{NO}_{8} \mathrm{P}: 718.5381$.

2b. Obtained $23.5 \mathrm{mg}$. Rf $\left.\left(\mathrm{CHCl}_{3}: \mathrm{MeOH}: \mathrm{H}_{2} \mathrm{O}, 65: 25: 04 \mathrm{v} / \mathrm{v} / \mathrm{v}\right) 0.58 ;{ }^{1} \mathrm{H} \mathrm{NMR} 400 \mathrm{MHz}, \mathrm{CDCl}_{3}\right) \delta_{\mathrm{H}}=8.49$ (br s, $\left.2.5 \mathrm{H}, \mathrm{NH}_{2} \rightleftharpoons \mathrm{NH}_{3}^{+}\right), 5.38-5.28(\mathrm{~m}, 4 \mathrm{H}, 2 \times \mathrm{Z}-\mathrm{CH}=\mathrm{CH}), 5.24-5.18(\mathrm{~m}, 1 \mathrm{H}, \mathrm{C}(1) \mathrm{H}), 4.37$ (dd, $J=12.0$, $3.0 \mathrm{~Hz}, 1 \mathrm{H}, \mathrm{C}(2) \mathrm{Hb}), 4.17-4.09\left(\mathrm{~m}, 3 \mathrm{H}, \mathrm{C}(1) \mathrm{Ha}+\mathrm{C}(3) \mathrm{H}_{2}\right), 3.95\left(\mathrm{t}, J=6 \mathrm{~Hz}, 2 \mathrm{H}, \mathrm{OCH}_{2} \mathrm{CH}_{2} \mathrm{NH}_{2}\right), 3.93(\mathrm{br} \mathrm{s}, 2 \mathrm{H}$, $\left.\mathrm{OCH}_{2} \mathrm{CH}_{2} \mathrm{NH}_{2}\right), 2.29\left(\mathrm{dd}, J=16.5,8.3 \mathrm{~Hz}, 4 \mathrm{H}, 2 \times \mathrm{CH}_{2} \mathrm{CH}_{2} \mathrm{COOR}\right), 2.01-1.93\left(\mathrm{~m}, 8 \mathrm{H}, 2 \times \mathrm{CH}_{2}-\mathrm{CH}=\mathrm{CH}-\mathrm{CH}_{2}\right)$, 1.58 (br s, $4 \mathrm{H}, 2 \times \mathrm{CH}_{2} \mathrm{CH}_{2} \mathrm{COOR}$ ), 1.39-1.22 (br s, $\left.40 \mathrm{H}, 20 \times \mathrm{CH}_{2}\right), 0.88\left(\mathrm{t}, J=10.0 \mathrm{~Hz}, 6 \mathrm{H}, 2 \times \mathrm{CH}_{3}\right) ;{ }^{13} \mathrm{C} \mathrm{NMR}$ $\left(100 \mathrm{MHz}, \mathrm{CDCl}_{3}\right): \delta_{\mathrm{C}}=14.3\left(\mathrm{CH}_{3}\right), 22.9\left(\mathrm{CH}_{2}\right), 25.1\left(\mathrm{CH}_{2}\right), 25.2\left(\mathrm{CH}_{2}\right), 27.4\left(\mathrm{CH}_{2}\right), 29.4\left(\mathrm{CH}_{2}\right), 29.5-29.8($ series of $\left.\mathrm{CH}_{2}\right), 30.0\left(\mathrm{CH}_{2}\right), 32.1\left(\mathrm{CH}_{2}\right), 34.3\left(\mathrm{CH}_{2}\right), 34.3\left(\mathrm{CH}_{2}\right), 40.7\left(\mathrm{CH}_{2} \mathrm{O}, \mathrm{HSQC}\right) 62.4(\mathrm{C} 3), 63.7(\mathrm{C} 1), 64.1\left(\mathrm{CH}_{2} \mathrm{~N}\right.$, HSQC), $70.6\left(\mathrm{C} 2\right.$, HSQC), $129.6(\mathrm{Z}-\mathrm{CH}=\mathrm{CH}), 130.2(\mathrm{Z}-\mathrm{CH}=\mathrm{CH}), 173.3(\mathrm{C}=\mathrm{O}), 173.6(\mathrm{C}=\mathrm{O}) ;{ }^{31} \mathrm{P} \mathrm{NMR}(121.5 \mathrm{MHz}$, $\left.\mathrm{CDCl}_{3}\right): \delta_{\mathrm{P}}=-2.24 ;[\alpha]_{\mathrm{D}}{ }^{25}=0.00\left(\mathrm{c} 0.1, \mathrm{CHCl}_{3}\right) ; \mathrm{HRMS} \mathrm{m} / \mathrm{z}:[\mathrm{M}]^{+}$calcd. for $\mathrm{C}_{41} \mathrm{H}_{78} \mathrm{NNaO}_{8} \mathrm{P}: 766.5339$, found $\mathrm{C}_{39} \mathrm{H}_{77 \mathrm{NO}_{8} \mathrm{P}: 766.5357 .}$

2c. Obtained $29.1 \mathrm{mg} . \mathrm{R}_{\mathrm{f}}\left(\mathrm{CHCl}_{3}: \mathrm{MeOH}: \mathrm{H}_{2} \mathrm{O}, 65: 25: 04 \mathrm{v} / \mathrm{v} / \mathrm{v}\right)$ 0.70; ${ }^{1} \mathrm{H} \mathrm{NMR}\left(400 \mathrm{MHz}, \mathrm{CDCl}_{3}\right)$ selected signals: $\delta_{\mathrm{H}}=5.24-5.18(\mathrm{~m}, 1 \mathrm{H}, \mathrm{C}(2) \mathrm{H}), 4.0 .2-3.99\left(\mathrm{~m}, 2 \mathrm{H}, \mathrm{C}(2) \mathrm{H}_{2}\right), 4.33-4.45\left(\mathrm{~m}, 2 \mathrm{H}, \mathrm{C}(3) \mathrm{H}_{2}\right), 4.27-4.19(\mathrm{~m}, 2 \mathrm{H}$, $\left.\mathrm{O}-\mathrm{CH}_{2}-\mathrm{CH}_{2}-\mathrm{NH}_{2}\right), 4.20-4.11\left(\mathrm{~m}, 2 \mathrm{H}, \mathrm{O}-\mathrm{CH}_{2}-\mathrm{CH}_{2}-\mathrm{NH}_{2}\right), 2.37-2.18\left(\mathrm{~m}, 4 \mathrm{H}, 2 \times \mathrm{CH}_{2} \mathrm{COOR}\right), 1.68-1.50(\mathrm{~m}, 4 \mathrm{H}$, $\left.\left.2 \times \mathrm{CH}_{2} \mathrm{CH}_{2} \mathrm{COOR}\right), 1.30,1.26\left(2 \times \mathrm{br}, 48 \mathrm{H}, 24 \times \mathrm{CH}_{2}\right), 0.88(\mathrm{t}, 6 \mathrm{H}, J=6.9 \mathrm{~Hz}), 6 \mathrm{H}, 2 \times \mathrm{CH} 3\right) .{ }^{13} \mathrm{C} \mathrm{NMR}(100 \mathrm{MHz}$, $\left.\mathrm{CDCl}_{3}\right): \delta_{\mathrm{C}}=$ (selected signals) $14.2\left(\mathrm{CH}_{3}\right), 25.1\left(\mathrm{CH}_{2}\right), 25.2\left(\mathrm{CH}_{2}\right), 29.5\left(\mathrm{CH}_{2}\right), 29.6\left(\mathrm{CH}_{2}\right), 29.8-29.9\left(\right.$ series of $\left.\mathrm{CH}_{2}\right)$, $30.6\left(\mathrm{CH}_{2}\right), 32.2\left(\mathrm{CH}_{2}\right), 34.4\left(\mathrm{CH}_{2}\right), 34.6\left(\mathrm{CH}_{2}\right), 65.5(\mathrm{C} 3), 65.6(\mathrm{C} 1), 70.6(\mathrm{C} 2, \mathrm{HSQC}), 173.6(\mathrm{C}=\mathrm{O}), 173.8(\mathrm{C}=\mathrm{O}) ;{ }^{31} \mathrm{P}$ NMR $\left(121.5 \mathrm{MHz}, \mathrm{CDCl}_{3}\right): \delta_{\mathrm{P}}=-2.45 ;[\alpha]_{\mathrm{D}}{ }^{25}=0.00\left(\mathrm{c} 0.1, \mathrm{CHCl}_{3}\right) ; \mathrm{HRMS} m / z:[\mathrm{M}]^{+}$calcd. for $\mathrm{C}_{37} \mathrm{H}_{75} \mathrm{NO}_{8} \mathrm{P}$ : 692.5230, found $\mathrm{C}_{37} \mathrm{H}_{75} \mathrm{NO}_{8} \mathrm{P}: 692.5225$.

\section{References}

1. Gal, J. When did Louis Pasteur present his memoir on the discovery of molecular chirality to the Académie des sciences? Analysis of a discrepancy. Chirality 2008, 20, 1072-1084. [CrossRef] [PubMed]

2. Garcia, A.; Meinert, C.; Sugahara, H.; Jones, N.; Hoffmann, S.; Meierhenrich, U. The Astrophysical Formation of Asymmetric Molecules and the Emergence of a Chiral Bias. Life 2019, 9, 29. [CrossRef] [PubMed]

3. Fiore, M. The Origin and Early Evolution of Life: Prebiotic Chemistry. Life 2019, 9, 73. [CrossRef] [PubMed]

4. Soai, K.; Shibata, T.; Morioka, H.; Choji, K. Asymmetric autocatalysis and amplification of enantiomeric excess of a chiral molecule. Nature 1995, 378, 767-768. [CrossRef]

5. Shibata, T.; Morioka, H.; Hayase, T.; Choji, K.; Soai, K. Highly enantioselective catalytic asymmetric automultiplication of chiral pyrimidyl alcohol. J. Am. Chem. Soc. 1996, 118, 471-472. [CrossRef]

6. Kawasaki, T.; Tanaka, H.; Tsutsumi, T.; Kasahara, T.; Sato, I.; Soai, K. Chiral discrimination of cryptochiral saturated quaternary and tertiary hydrocarbons by asymmetric autocatalysis. J. Am. Chem. Soc. 2006, 128, 6032-6033. [CrossRef]

7. Hargreaves, W.R.; Deamer, D.W. Liposomes from ionic, single-chain amphiphiles. Biochemistry 1978, 17, 3759-3768. [CrossRef]

8. Albertsen, A.N.; Duffy, C.D.; Sutherland, J.D.; Monnard, P.-A. Self-Assembly of Phosphate Amphiphiles in Mixtures of Prebiotically Plausible Surfactants. Astrobiology 2014, 14, 462-472. [CrossRef] 
9. Fiore, M.; Madanamoothoo, W.; Berlioz-Barbier, A.; Maniti, O.; Girard-Egrot, A.; Buchet, R.; Strazewski, P. Giant vesicles from rehydrated crude mixtures containing unexpected mixtures of amphiphiles formed under plausibly prebiotic conditions. Org. Biomol. Chem. 2017, 15, 4231-4240. [CrossRef]

10. Fiore, M. The synthesis of mono-alkyl phosphates and their derivatives: An overview of their nature, preparation and use, including synthesis under plausible prebiotic conditions. Org. Biomol. Chem. 2018, 16, 3068-3086. [CrossRef]

11. Powner, M.W.; Sutherland, J.D. Prebiotic chemistry: A new modus operandi. Philos. Trans. R. Soc. B Biol. Sci. 2011, 366, 2870-2877. [CrossRef] [PubMed]

12. Ourisson, G.; Nakatani, Y. The terpenoid theory of the origin of cellular life: The evolution of terpenoids to cholesterol. Chem. Biol. 1994, 1, 11-23. [CrossRef]

13. Hanczyc, M.M.; Monnard, P.-A.A. Primordial membranes: More than simple container boundaries. Curr. Opin. Chem. Biol. 2017, 40, 78-86. [CrossRef] [PubMed]

14. Hargreaves, W.R.; Mulvil, S.J.; Deamer, D.W. Synthesis of phospholipids and membranes in prebiotic conditions. Nature 1977, 266, 78-80. [CrossRef]

15. Epps, D.E.; Sherwood, E.; Eichberg, J.; Oró, J. Cyanamide mediated syntheses under plausible primitive earth conditions. J. Mol. Evol. 1978, 11, 279-292. [CrossRef] [PubMed]

16. Rao, M.; Eichberg, J.; Oró, J. Synthesis of phosphatidylcholine under possible primitive Earth conditions. J. Mol. Evol. 1982, 18, 196-202. [CrossRef]

17. Rao, M.; Eichberg, J.; Oró, J. Synthesis of phosphatidylethanolamine under possible primitive earth conditions. J. Mol. Evol. 1987, 25, 1-6. [CrossRef]

18. Fayolle, D.; Altamura, E.; D’Onofrio, A.; Madanamothoo, W.; Fenet, B.; Mavelli, F.; Buchet, R.; Stano, P.; Fiore, M.; Strazewski, P. Crude phosphorylation mixtures containing racemic lipid amphiphiles self-assemble to give stable primitive compartments. Sci. Rep. 2017, 7, 18106. [CrossRef]

19. Rushdi, A.I.; Simoneit, B.R.T.T. Abiotic condensation synthesis of glyceride lipids and wax esters under simulated hydrothermal conditions. Orig. Life Evol. Biosph. 2006, 36, 93-108. [CrossRef]

20. Canavelli, P.; Islam, S.; Powner, M.W. Peptide ligation by chemoselective aminonitrile coupling in water. Nature 2019, 571, 546-549. [CrossRef]

21. Gilbert, W. Origin of life: The RNA world. Nature 1986, 319, 618. [CrossRef]

22. Tamura, K. Origin of amino acid homochirality: Relationship with the RNA world and origin of tRNA aminoacylation. BioSystems 2008, 92, 91-98. [CrossRef]

23. Park, J.W. Effect of phospholipid bilayer phase asymmetry on phospholipase D reaction-induced vesicle rupture. J. Membr. Biol. 2011, 244, 55-59. [CrossRef] [PubMed]

24. Hitz, T.; Luisi, P.L. Enhancement of Homochirality in Oligopeptides by Quartz. Helv. Chim. Acta 2002, 85, 3975-3983. [CrossRef]

25. Ishigami, T.; Suga, K.; Umakoshi, H. Chiral Recognition of L-Amino Acids on Liposomes Prepared with L-Phospholipid. ACS Appl. Mater. Interfaces 2015, 7, 21065-21072. [CrossRef]

26. Hirose, M.; Ishigami, T.; Suga, K.; Umakoshi, H. Liposome Membrane as a Platform for the 1 -Pro-Catalyzed Michael Addition of trans- $\beta$-Nitrostyrene and Acetone. Langmuir 2015, 31, 12968-12974. [CrossRef]

27. Stano, P.; Altamura, E.; Mavelli, F. Novel directions in molecular systems design: The case of light-transducing synthetic cells. Commun. Integr. Biol. 2017, 10, 3837-3842. [CrossRef]

28. D'Aguanno, E.; Altamura, E.; Mavelli, F.; Fahr, A.; Stano, P.; Luisi, P.L. Physical routes to primitive cells: An experimental model based on the spontaneous entrapment of enzymes inside Micrometer-Sized liposomes. Life 2015, 5, 969-996. [CrossRef]

29. Altamura, E.; Stano, P.; Walde, P.; Mavelli, F. Giant vesicles as micro-sized enzymatic reactors: Perspectives and recent experimental advancements. Int. J. Unconv. Comput. 2015, 11, 5-21.

30. Altamura, E.; Milano, F.; Tangorra, R.R.; Trotta, M.; Omar, O.H.; Stano, P.; Mavelli, F. Highly oriented photosynthetic reaction centers generate a proton gradient in synthetic protocells. Proc. Natl. Acad. Sci. USA 2017, 114, 3837-3842. [CrossRef] [PubMed]

31. Fayolle, D.; Fiore, M.; Stano, P.; Strazewski, P. Rapid purification of giant lipid vesicles by microfiltration. PLoS ONE 2018, 13, e0192975. [CrossRef] [PubMed]

32. Fiore, M.; Maniti, O.; Girard-Egrot, A.; Monnard, P.-A.A.; Strazewski, P. Glass Microsphere-Supported Giant Vesicles for the Observation of Self-Reproduction of Lipid Boundaries. Angew. Chem. Int. Ed. 2018, 57, 282-286. [CrossRef] 
33. Miele, Y.; Medveczky, Z.; Holló, G.; Tegze, B.; Derényi, I.; Hórvölgyi, Z.; Altamura, E.; Lagzi, I.; Rossi, F. Self-division of giant vesicles driven by an internal enzymatic reaction. Chem. Sci. 2020, 11, 3228-3235. [CrossRef]

34. Lopez, A.; Fiore, M. Investigating Prebiotic Protocells for a Comprehensive Understanding of the Origins of Life: A Prebiotic Systems Chemistry Perspective. Life 2019, 9, 49. [CrossRef] [PubMed]

35. Eibl, H. Phospholipids as Functional Constituents of Biomembranes. Angew. Chemie Int. Ed. 1984, 23, 257-271. [CrossRef]

36. Paltauf, F.; Hermetter, A. Strategies for the synthesis of glycerophospholipids. Prog. Lipid Res. 1994, 33, 239-328. [CrossRef]

37. Burgos, C.E.; Ayer, D.E.; Johnson, R.A. A new, asymmetric synthesis of lipids and phospholipids. J. Org. Chem. 1987, 52, 4973-4977. [CrossRef]

38. Lindberg, J.; Ekeroth, J.; Konradsson, P. Efficient synthesis of phospholipids from glycidyl phosphates. J. Org. Chem. 2002, 67, 194-199. [CrossRef] [PubMed]

39. Roodsari, F.S.; Wu, D.; Pum, G.S.; Hajdu, J. A new approach to the stereospecific synthesis of phospholipids. The use of L-glyceric acid for the preparation of diacylglycerols, phosphatidylcholines, and related derivatives. J. Org. Chem. 1999, 64, 7727-7737. [CrossRef]

40. Fiore, M.; Strazewski, P. Prebiotic lipidic amphiphiles and condensing agents on the early earth. Life 2016, 6, 17. [CrossRef]

41. Baran, J.S.; Langford, D.D.; Laos, I. Displacement Reactions of Cyclic Sulfites and Phosphates by Salts of Weak Acids Applicable to the Synthesis of Phospholipids and Other Natural Substances. J. Org. Chem. 1977, 42, 2260-2264. [CrossRef]

42. Perosa, A.; Moraschini, A.; Selva, M.; Noè, M. Synthesis of the Fatty Esters of Solketal and Glycerol-Formal: Biobased Specialty Chemicals. Molecules 2016, 21, 170. [CrossRef] [PubMed]

43. Tyurina, Y.Y.; Lou, W.; Qu, F.; Tyurin, V.A.; Mohammadyani, D.; Liu, J.; Hüttemann, M.; Frasso, M.A.; Wipf, P.; Bayir, H.; et al. Lipidomics Characterization of Biosynthetic and Remodeling Pathways of Cardiolipins in Genetically and Nutritionally Manipulated Yeast Cells. ACS Chem. Biol. 2017, 12, 265-281. [CrossRef]

44. Neises, B.; Steglich, W. Simple Method for the Esterification of Carboxylic Acids. Angew. Chemie Int. Ed. 1978, 17, 522-524. [CrossRef]

45. Rytczak, P.; Koziołkiewicz, M.; Okruszek, A. The chemical synthesis of phosphorothioate and phosphorodithioate analogues of lysophosphatidic acid (LPA) and cyclic phosphatidic acid (CPA). New J. Chem. 2010, 34, 1008. [CrossRef]

46. Jeong, S.W.; O'Brien, D.F. Synthesis of a polymerizable metal-ion-chelating lipid for fluid bilayers. J. Org. Chem. 2001, 66, 4799-4802. [CrossRef] [PubMed]

47. Hemström, P.; Larsson, A.; Elfsmark, L.; Åstot, C. $\alpha$-Phosphatidylglycerol Chlorohydrins as Potential Biomarkers for Chlorine Gas Exposure. Anal. Chem. 2016, 88, 9972-9979. [CrossRef] [PubMed]

48. Burgula, S.; Swarts, B.M.; Guo, Z. Total synthesis of a glycosylphosphatidylinositol anchor of the human lymphocyte CD52 antigen. Chem. A Eur. J. 2012, 18, 1194-1201. [CrossRef] [PubMed]

49. Starck, J.-P.; Nakatani, Y.; Ourisson, G. Synthesis of two new phospholipidic fluorescent probes for membrane studies. Tetrahedron 1995, 51, 2629-2638. [CrossRef]

50. Jeon, O.Y.; Carreira, E.M. Differential interaction of an AmB Analogue and ergosterol in enantiomeric membranes. Org. Lett. 2010, 12, 1772-1775. [CrossRef]

51. Walde, P.; Cosentino, K.; Engel, H.; Stano, P. Giant Vesicles: Preparations and Applications. ChemBioChem 2010, 11, 848-865. [CrossRef] [PubMed]

52. Pautot, S.; Frisken, B.J.; Weitz, D.A. Production of unilamellar vesicles using an inverted emulsion. Langmuir 2003, 19, 2870-2879. [CrossRef]

53. Altamura, E.; Carrara, P.; D'Angelo, F.; Mavelli, F.; Stano, P. Extrinsic stochastic factors (solute partition) in gene expression inside lipid vesicles and lipid-stabilized water-in-oil droplets: A review. Synth. Biol. 2018, 3. [CrossRef]

54. Altamura, E. Light-driven ATP production promotes mRNA biosynthesis inside hybrid multi-compartment artificial protocells. bioRxiv 2020. [CrossRef]

55. Stamatov, S.D.; Gronowitz, S. Glyceroamidothiophosphates of cholecalciferol (Vitamin D3). Lipids 1990, 25, 149-151. [CrossRef] 
56. Ramstedt, B.; Slotte, J.P. Comparison of the Biophysical Properties of Racemic and d-Erythro-N-Acyl Sphingomyelins. Biophys. J. 1999, 77, 1498-1506. [CrossRef]

57. Cohen, B.E.; Bangam, A.D. Diffusion of Small Non-Electrolytes across Liposome Membranes. Nature 1972, 236, 173-174. [CrossRef]

58. Morigaki, K.; Dallavalle, S.; Walde, P.; Colonna, S.; Luisi, P.L. Autopoietic self-reproduction of chiral fatty acid vesicles. J. Am. Chem. Soc. 1997, 119, 292-301. [CrossRef]

59. Moreno, A.; Ruiz-Mirazo, K. The problem of the emergence of functional diversity in prebiotic evolution. Biol. Philos. 2009, 24, 585-605. [CrossRef]

60. Ruiz-Mirazo, K.; Mavelli, F. On the way towards "basic autonomous agents": Stochastic simulations of minimal lipid-peptide cells. BioSystems 2008, 91, 374-387. [CrossRef]

61. Ruiz-Mirazo, K.; Mavelli, F. Simulation model for functionalized vesicles: Lipid-peptide integration in minimal protocells. Lect. Notes Comput. Sci. Subser. Lect. Notes Artif. Intell. Lect. Notes Bioinform. 2007, 4648, 32-41. [CrossRef]

(C) 2020 by the authors. Licensee MDPI, Basel, Switzerland. This article is an open access article distributed under the terms and conditions of the Creative Commons Attribution (CC BY) license (http://creativecommons.org/licenses/by/4.0/). 